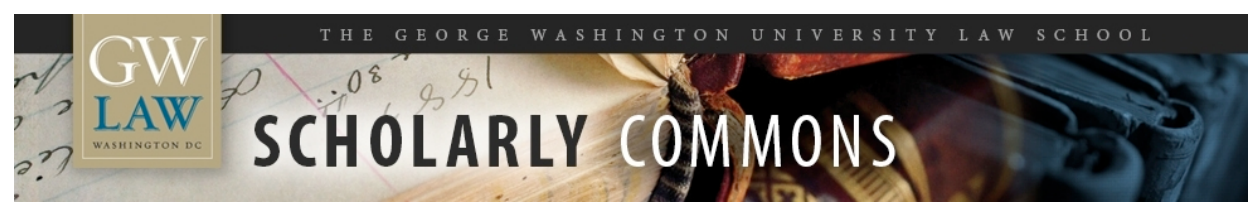

\title{
The Trans Panic Defense: Heteronormativity, and the Murder of Transgender Women
}

\author{
Cynthia Lee \\ George Washington University Law School, cylee@law.gwu.edu \\ Peter Kar Yu Kwan \\ Golden Gate University School of Law
}

Follow this and additional works at: https://scholarship.law.gwu.edu/faculty_publications

Part of the Law Commons

\section{Recommended Citation}

Lee, Cynthia and Kwan, Peter Kar Yu, The Trans Panic Defense: Heteronormativity, and the Murder of Transgender Women (2014). 66 Hastings L.J. 77 (2014); GWU Law School Public Law Research Paper No. 2014-10; GWU Legal Studies Research Paper No. 2014-10. Available at SSRN: http://ssrn.com/ abstract $=2430390$ or http://dx.doi.org/10.2139/ssrn.2430390

This Article is brought to you for free and open access by the Faculty Scholarship at Scholarly Commons. It has been accepted for inclusion in GW Law Faculty Publications \& Other Works by an authorized administrator of Scholarly Commons. For more information, please contact spagel@law.gwu.edu. 


\title{
The Trans Panic Defense: Masculinity, Heteronormativity, and the Murder of Transgender Women
}

\author{
Cynthia LeE* and Peter Kwan**
}

When a heterosexual man is charged with murdering a transgender woman with whom he has been sexually intimate, one defense strategy is to assert what has been called the trans panic defense. The defendant claiming this defense will say that the discovery that the victim was biologically male provoked him into a heat of passion causing him to lose self-control. If the jury finds that the defendant was actually and reasonably provoked, it can acquit him of murder and find him guilty of the lesser offense of voluntary manslaughter. The trans panic defense strategy is troubling because it appeals to stereotypes about transgender individuals as sexually deviant and abnormal.

In this article, we examine the cultural structures of masculinity that may lead a man to kill a transgender woman with whom he has been sexually intimate. Building on Professor Angela Harris' important work on male-on-male violence, we argue that

* Charles Kennedy Poe Research Professor of Law, The George Washington University Law School. Cynthia Lee thanks Omar Clarke, a transgender male co-worker at The George Washington University Law School, for sharing his insights about transgender people and the process of transitioning. Cynthia Lee thanks Carrie James, Erin Mick, Prerna Lal, Andrew Basham, and Matthew Halldorson for research assistance on this paper. Cynthia Lee also thanks Nicholas Stark for his expertise and assistance in finding difficult-to-locate resources.

** B.A., University of Sydney (with Honors); LL.M., University of Sydney (with Honors); LL.M., Columbia University.

The Authors thank I. Bennett Capers, Joshua Dressler, Arnold Loewy, Kevin McGunigal, Steve Morrison, Michael Rich, and Susan Rozelle for helpful suggestions when Cynthia Lee presented this paper at Texas Tech School of Law's Annual Criminal Law Symposium on April 4, 20I4. We also thank Gabriel Jack Chin, Chris Elmendorf, Angela Harris, Courtney Joslin, Miguel Mendez, former California Supreme Court Justice Cruz Reynoso, and students in Angela Harris's Spring 20I4 Criminal Law class for helpful comments and feedback when Cynthia Lee presented the paper at UC Davis School of Law in March 20I4. We would also like to thank Robert Chang, Anupam Chander, Susan Kuo, Andrea Freeman, Leah Grinvald, and Miye Goishi, who provided more helpful feedback when Cynthia Lee presented this paper at CAPALF at UC Hastings College of the Law in San Francisco, California in February 2013. We also thank Stephen Galoub, Melissa Hamilton, Carissa Hessick, Anna Roberts, Danielle Tyson, and others for their comments and suggestions for improvement when Cynthia Lee presented a very early draft of this paper at Law and Society in June 20I2. Additional thanks go to Josephine Ross and Kelly Strader for their helpful comments. 
violence by men against transgender women is a variant of gender violence that has not received the attention it deserves. We examine how masculinities theories can unmask the motivations behind the trans panic defense and discuss ways in which structures of masculinity can encourage juries to find that the defendant who claims trans panic was reasonably provoked.

Most critics of the trans panic defense strategy have argued that defendants should be banned from making trans panic arguments. Instead of advocating a ban on this defense strategy, we offer a tool kit of strategies for prosecutors to combat claims of trans panic. One of several suggestions we offer is a rephrasing of terminology, replacing the phrase "trans panic" with "trans rage." We also argue that the current understanding of reasonableness in provocation doctrine-reasonableness as that which is typical-is misguided. We suggest reasonableness is better understood as a normative limitation on the provocation defense. 
TABle of CONTEnTS

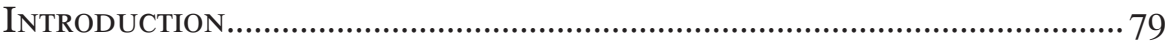

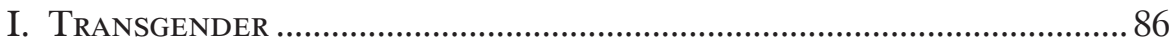

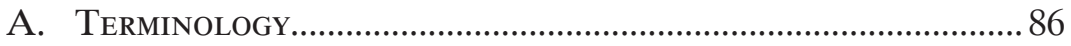

B. Violence Against Transgender Persons................................. 94

II. Provocation and Trans Panic ............................................................ 97

A. The Doctrine of Provocation................................................. 98

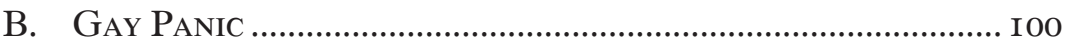

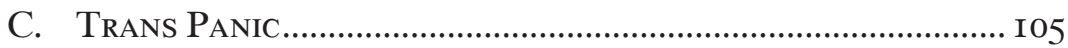

III. Behind the Claims of Trans Panic ................................................. I08

A. Protection of the Masculine Identity and the Fear of Being SEen as Gay.

B. Sexual Prejudice and the Enforcement of Gender NORMS ....

C. Blaming the Victim for Her Alleged Deceit ...................... I I 3

IV. Legislative Bans and Other Proposals for Reform....................... I I 9

CONCLUSION ……….............................................................................. I32

\section{INTRODUCTION}

RESOLVED, That the American Bar Association urges federal, tribal, state, local and territorial governments to take legislative action to curtail the availability and effectiveness of the "gay panic" and "trans panic" defenses, which seek to partially or completely excuse crimes such as murder and assault on the grounds that the victim's sexual orientation or gender identity is to blame for the defendant's violent reaction. Such legislative action should include:

(a) Requiring courts in any criminal trial or proceeding, upon the request of a party, to instruct the jury not to let bias, sympathy, prejudice, or public opinion influence its decision about the victims, witnesses, or defendants based upon sexual orientation or gender identity; and

(b) Specifying that neither a non-violent sexual advance, nor the discovery of a person's sex or gender identity, constitutes legally adequate provocation to mitigate the crime of murder to manslaughter, or to mitigate the severity of any non-capital crime. ${ }^{\mathrm{I}}$

On August I2, 20I3, the House of Delegates of the American Bar Association ("ABA") unanimously passed a resolution aimed at combating the discriminatory effects of gay and trans panic defenses. ${ }^{2}$ "Gay panic" and "trans panic" are not officially recognized criminal law

I. Am. Bar Ass'n, Res. II3A, at I (2013), available at http://gbtbar.org/wpcontent/uploads/2014/02/Gay-and-Trans-Panic-Defenses-Resolution.pdf.

2. Terry Carter, 'Gay Panic' Criminal Defense Strategies Should Be Curtailed by Legislation, ABA House Resolves, A.B.A. J. (Aug. I2, 2013, 9:40 PM), www.abajournal.com/news/article/resolution_ on_gay_panic. 
defenses, but are defense strategies used to lend support to traditional criminal law defenses like temporary insanity, provocation, or selfdefense. The defendant claiming gay panic will assert that his gay male victim's unwanted homosexual advance provoked him into a heat of passion or caused him to lose his mind, and therefore the jury should find him not guilty of murder. ${ }^{3}$ Similarly, the defendant claiming trans panic will argue that the post-intimate discovery that his transgender female victim had male genitalia was so upsetting that it provoked him into a heat of passion. ${ }^{4}$ Provocation is a partial defense to murder. When successful, it usually results in the mitigation of an intentional killing that would otherwise be murder to voluntary manslaughter.

The ABA resolution contains two parts. First, the resolution urges legislatures to enact laws requiring judges to give anti-bias jury instructions upon the request of either party. 5 Second, it calls upon legislatures to pass legislation specifying that neither a nonviolent sexual advance nor the discovery of a person's sex or gender identity constitutes legally adequate provocation to mitigate the severity of any noncapital crime. $^{6}$

The ABA should be commended for taking concrete action to try to combat bias against gay men and transgender women. ${ }^{7}$ The Authors of this Article share the ABA's concern that gay and trans panic defense strategies promote negative stereotypes about gay men and transgender women as sexual deviants. We fully support laws requiring judges to give anti-bias jury instructions upon request of either party. We question, however, whether a legislative ban is the best way to combat the bias that gay and trans panic defense strategies reflect. While a ban would serve an important expressive function, it might not be sufficient, in and of itself, to eviscerate the underlying structures of masculinity that encourage the use of gay and trans panic strategies. ${ }^{8}$ We therefore

3. Cynthia Lee, The Gay Panic Defense, 42 U.C. Davis L. Rev. 47I, 500 (2008).

4. See Victoria L. Steinberg, A Heat of Passion Offense: Emotions and Bias in "Trans Panic" Mitigation Claims, 25 B.C. Third World L.J. 499, 500-0i (2005) (reviewing Martha C. Nussbaum, Hiding FROM HUMANITY (2004)).

5. Am. Bar Ass'n, supra note 1, at I.

6. Id.

7. While a ban on gay and trans panic arguments could theoretically protect all individuals in the Lesbian, Gay, Bisexual, Transgender, and Questioning ("LGBTQ") community, gay panic is usually asserted by heterosexual male defendants charged with murdering gay men, and trans panic is usually asserted by heterosexual men charged with murdering transgender women.

8. We note that many progressive scholars warn against wholehearted support of measures that make it easier for the State to incarcerate individuals, because such reforms often end up disproportionately harming poor people and people of color. See, e.g., Joey L. Mogul ET AL., QueER (In)Justice: The Criminalization of LGBT People in the United States I44-45 (20I I) (noting that many in the LGBT community reject reforms that expand police power because such reforms often end up disproportionately harming poor people and people of color); Aya Gruber, Murder, Minority Victims, and Mercy, 85 Colo. L. Rev. I29, I29-30 (2014) (arguing that limiting the provocation 
suggest alternative ways to undermine the chances that a panic defense strategy will succeed. Our proposals are aimed at raising public awareness of the structures of masculinity that make appeals to gay and trans panic arguments persuasive.

Because the gay panic defense strategy has been discussed at length elsewhere, ${ }^{9}$ the primary focus of this Article is the trans panic defense strategy. Only a handful of law review articles have focused on the trans panic defense strategy. ${ }^{10}$ None of these articles examine whether the ABA's recent resolution is the best way to address the problem of bias against transgender individuals that lies at the root of why trans panic strategies have traction. We attempt to fill this void by examining the cultural structures of masculinity that may lead a man to kill a

defense would have a disproportionate impact on less privileged men of color); Aya Gruber, The Feminist War on Crime, 92 Iowa L. Rev. 74I, 824 (2007) ("Feminists should not be channeling their efforts into helping the government find new, better, and easier ways to incarcerate people (most likely minority people), while remaining relatively silent on the government's and society's maintenance of patriarchy."); Aya Gruber, Rape, Feminism, and the War on Crime, 84 WASH. L. Rev. 58I, 657 (2009) ("[I]ncreasing the prosecutorial power of the state is an endeavor in which, at this particular moment, feminists should no longer enlist."); Aya Gruber, Neofeminism, 50 Hous. L. Rev. I325, I330 (2013) ("State power, like an eager tenant, can and will quickly take up residence in the architecture of progressive legal experiments.").

9. See, e.g., Lee, supra note 3, at 48I (arguing that making sexual orientation salient is a better way to deal with problems of anti-gay bias than a judicial or legislative ban); Joshua Dressler, When "Heterosexual" Men Kill "Homosexual" Men: Reflections on Provocation Law, Sexual Advances, and the "Reasonable Man" Standard, 85 J. CRIm. L. \& Criminology 726, 726-32 ( I995) (critiquing Mison's conception of the reasonable man); Robert B. Mison, Homophobia in Manslaughter: The Homosexual Advance as Insufficient Provocation, 8o Calif. L. Rev. I33, I36 (I992) (arguing that judges should rule, as a matter of law, that a nonviolent homosexual advance is not legally adequate provocation); J. Kelly Strader et al., Gay Panic and the Case for Gay Shield Laws (2014) (unpublished manuscript) (on file with Cynthia Lee) (providing an excellent analysis of the shooting of a I5-year-old gender nonconforming teen named Larry King by his I4-year-old classmate Brandon McInerney and proposing "gay shield" laws modeled after rape shield laws to minimize bias against the gay male or gender nonconforming victim in gay panic cases); Developments in the Law-Sexual Orientation and the Law, I02 Harv. L. Rev. I508, I542-46 (1989); Gary David Comstock, Dismantling the Homosexual Panic Defense, 2 L. \& Sexuality: A Rev. of Lesbian \& Gay Legal Issues 8I, 8I-82 (ig92); Martha C. Nussbaum, Secret Sewers of Vice, in The Passions of Law 30, 35-38 (Susan A. Bandes ed., I999); David Alan Perkiss, A New Strategy for Neutralizing the Gay Panic Defense at Trial: Lessons from the Lawrence King Case, 6o UCLA L. Rev. 778, 784 (2013) (building on Lee's suggestion that prosecutors should make sexual orientation salient rather than ban the gay panic defense); Kara S. Suffredini, Pride and Prejudice: The Homosexual Panic Defense, 2I B.C. Third World L.J. 279, 279, 302 (200I); Christina Pei-Lin Chen, Note, Provocation's Privileged Desire: The Provocation Doctrine, "Homosexual Panic," and the Non-Violent Unwanted Sexual Advance Defense, io Cornell J.L. \& Pub. Pol'y 195, 20I-03, 210-13. (2000); Alexis Kent, Comment, A Matter of Law: The Non-Violent Homosexual Advance Defense Is Insufficient Evidence of Provocation, 44 U.S.F. L. Rev. I55 (2009). See also Duncan Osborne, The Homosexual Panic Defense: Are Juries Really Buying It?, LGNY News, Nov. 4, I999, at 4.

Io. See, e.g., Morgan Tilleman, (Trans)forming the Provocation Defense, ioo J. CRim. L. \& Criminology I659 (2010); Steinberg, supra note 4; Bradford Bigler, Sexually Provoked: Recognizing Sexual Misrepresentation as Adequate Provocation, 53 UCLA L. Rev. 783 (2006); Teresa Marie Garmon, The Panic Defense and Model Rules Common Sense: A Practical Solution for a TwentyFirst Century Ethical Dilemma, 45 GA. L. Rev. 62I (201 I). 
transgender woman with whom he has been sexually intimate and make his claim of provocation appear reasonable. Building on Professor Angela Harris' important work on male-on-male violence, ${ }^{\text {II }}$ we argue that violence by men against transgender women is a type of "gender violence" that has gone largely unexamined until now. In an attempt to undermine the appeal of trans panic, this Article excavates the structures of heteronormativity ${ }^{12}$ that provide invisible support for claims of trans panic.

This Article proceeds in four parts. Part I begins the process of raising awareness - a process critical to our end goal of reducing bias against transgender individuals. It starts by defining terminology. For many, words like "transgender," "transsexual," "intersexual," "transvestite," and "gender identity" are not common and familiar terms. Even the difference between the terms "sex" and "gender" is not selfevident to many people. Part I tries to demystify these terms by explaining their commonly understood meanings.

Part I also provides a broad overview of the problem of violence against transgender persons. One problem with trying to assess the extent of this violence is that, until recently, there was no nationwide mechanism for the collection of statistics on violence against transgender victims. A few private organizations have tried to address this problem by collecting their own data on violence against transgender persons, and we report their findings here. Another problem is that even in states that do include gender identity bias in their hate crime laws, law enforcement officers often do not report hate crimes based on gender identity bias because they do not recognize anti-transgender bias as such. Many police officers think hate crimes against transgender victims are crimes based on sexual orientation, even though they are better understood as crimes based on gender identity, because the officers do not understand what it means to be a transgender individual. ${ }^{13}$

Part II focuses on the doctrinal underpinnings of the trans panic defense strategy. It starts by examining the doctrine of provocation in its

I I. Angela P. Harris, Gender, Violence, Race, and Criminal Justice, 52 Stan. L. Rev. 777, 780 (2000) (discussing violent acts committed by men against other men as "gender violence").

I2. Kimberly Kiesewetter, Catfish and the Influences of Heteronormativity, Soc. IN Focus (Mar. I I, 20I3), http://www.sociologyinfocus.com/20I3/03/I I/catfish-and-the-influences-of-heteronormativity (defining heteronormativity as "the belief that heterosexuality is the only acceptable sexual orientation"); Nancy J. Knauer, Heteronormativity and Federal Tax Policy, IoI W. VA. L. Rev. I29, I33 (I998) (defining heteronormativity as "the largely unstated assumption that heterosexuality is the essential and elemental ordering principal of society"); Kimberly Kiesewetter, Catfish and the Influences of Heteronormativity, Soc. IN Focus (Mar. II, 2013), http://www.sociologyinfocus.com/2013/03/I I/catfish-and-the-influences-of-heteronormativity (defining heteronormativity as "the belief that heterosexuality is the only acceptable sexual orientation").

13. Rebecca L. Stotzer, Violence Against Transgender People: A Review of United States Data, I4 Aggression \& Violent Behav. I70, I76 (2009). 
various forms, from its early common law roots to its use today in murder cases involving gay and transgender victims. Provocation law generally requires proof that the defendant was actually provoked into a heat of passion and that the provocation was legally adequate. ${ }^{14}$ In modern jurisdictions, legally adequate provocation exists if the reasonable person would have been provoked into a heat of passion. ${ }^{15}$ Most courts understand reasonableness in the provocation context as a descriptive limitation, equating it with typicality. ${ }^{16}$ Under this view, the reasonable person in provocation law is the average, ordinary person. ${ }^{17}$ We argue that equating reasonableness with typicality is problematic because it allows the average man's fear of being seen as gay to excuse fatal acts of violence against transgender women.

Part III examines three possible motivations behind the violence in trans panic cases and assesses whether any of these motivations ought to count as legally adequate provocation. First, the defendant's violence may be motivated by his fear of being seen as gay. The male defendant who kills a transgender woman with whom he has been sexually intimate may believe that his attraction to someone he later learns is biologically male reflects his own latent homosexuality. He may be afraid that if others find out that he was sexually intimate with a transgender woman, they will think he is gay. ${ }^{18}$ Just as fear of being seen as a coward should not constitute legally adequate provocation, a murder defendant's fear of being seen as gay should not be considered a legitimate reason for losing one's self-control.

Second, the defendant's violence may be motivated by the defendant's extreme discomfort with gender nonconformity. His act of killing reflects a desire to enforce prevailing gender norms that align sex with gender. ${ }^{19}$ The common way of thinking about gender sees male and female, masculine and feminine as binary opposites. ${ }^{20}$ The transgender woman transgresses gender norms by assuming a female identity when she was born with male anatomy. The defendant punishes her act of transgression by killing her. The law, however, generally disapproves of acts of violence that are motivated by a desire to enforce gender norms.

I4. Joshua Dressler, Understanding Criminal Law $§ 3$ I.07 (6th ed. 20i2).

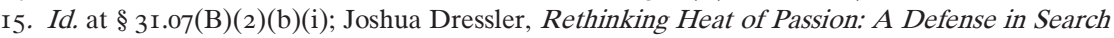
of a Rationale, 73 J. CRIM. L. \& CRIminology 42 I, 430 ( I982).

I6. Dressler, supra note I4, at § 3I.07(B)(2)(b)(ii); see also Dressler, supra note 9, at 753 ("The Reasonable Man in the context of provocation law . . . is more appropriately described as the Ordinary Man (i.e., a person who possesses ordinary human weaknesses).").

I7. Dressler, supra note I4, at \$3I.07(B)(2)(b)(i).

I8. The man who kills a male-to-female transgender person believes that the victim's true sex is male and therefore, any sex he had with the victim was homosexual sex. The trans woman who prefers to date straight men, however, is heterosexual.

I9. See infra Part I.A.

20. See infra Part I.A. 
Bullying of gay and lesbian youth, for example, is widely condemned. Likewise, the law of provocation should not countenance the use of violence to enforce gender norms in the trans panic context.

Third, the defendant's violence may be motivated by his anger at the victim's alleged deceit or misrepresentation regarding her gender identity. The defendant may feel the victim deceived him by pretending to be a woman when she was, in the defendant's view, actually a man. The defendant claims that the discovery of the victim's "true" gender identity - finding out that the victim was a "he" rather than a "she"-and the feeling of betrayal stemming from the victim's deceit upset him so much that he lost his self-control and was reasonably provoked into a heat of passion. In examining whether the transgender victim's alleged deceit should partially excuse the defendant's fatal loss of self-control, we assess the defendant's claim of deceit against the fraud-in-the-factum and fraud-in-the-inducement distinction found in rape law and conclude that the law of provocation should not permit mitigation on the basis of the defendant's anger at the victim's alleged deceit.

In Part IV, we discuss various ways legal actors involved in the criminal justice system might act to combat the bias against transgender individuals that inheres in trans panic cases. Most of the existing legal literature on this topic, like the ABA resolution, advocates banning gay and trans panic arguments either legislatively or judicially. ${ }^{2 \mathrm{I}} \mathrm{We}$ acknowledge that a legislative ban can serve a valuable expressive function but caution that unless steps are taken to reduce bias against transgender individuals, a ban is unlikely to ensure murder convictions in all cases in which a defendant argues that he was so upset by the discovery that he was sexually intimate with someone he thought was female but was biologically male that he killed her. Indeed, a ban could have the unintended consequence of more acquittals or hung juries in jurisdictions where the community sees transgender individuals as unnatural and deviant. In such jurisdictions, if jurors are faced with an all or nothing choice, they may opt to acquit the defendant because they have not been given legal permission to find the defendant guilty of manslaughter. An additional concern is that a legislative ban on a defense argument in one arena might open the door to legislative bans on defense arguments in other contexts. When the defense is one that is construed as a case-in-chief defense, as the defense of provocation typically is, this is all the more problematic since the prosecution bears the burden of proving every essential element of the charged offense and disallowing the defense lessens the prosecution's burden of proof.

Instead of a ban, we offer a tool kit to help prosecutors combat the trans panic defense strategy. First, we suggest that prosecutors try to 
humanize the transgender victim so the jury can see the victim as a person worthy of empathy. As is common in other homicide cases, the prosecutor can humanize the victim by bringing in witnesses to talk about the victim. Prosecutors should educate jurors about what it means to be a transgender individual. They should also educate jurors about the cultural structures of masculinity that contribute to violence against transgender individuals in general, and transgender women in particular. Finally, prosecutors can change the tone of the debate by referring to the defense strategy as "trans rage," rather than "trans panic." Parts I and II of this Article are aimed at assisting prosecutors in this project of education.

Prosecutors who attempt to do these things are likely to face objections from the defense on the ground that character evidence regarding the victim is irrelevant. The defense will argue that the only thing the jury should be concerned with is the state of mind of the defendant, not what the victim was experiencing or feeling. Moreover, the defense is likely to argue that if cultural structures of masculinity encourage men in this society to think it is unmanly to be gay, this kind of evidence actually supports the defendant's claim that it was reasonable for him to be provoked into a heat of passion by the discovery that the victim was biologically male. We address both of these objections in Part IV.

Second, we propose that judges clarify to juries that the requirement of "legally adequate provocation" is a normative limitation on the provocation defense. Instead of being told that the defendant can receive the provocation mitigation as long as a reasonable person would have been provoked, the jury should be instructed that a murder defendant is not entitled to receive the provocation mitigation unless his or her loss of self-control was normatively reasonable. In other words, whether the defendant should receive the provocation mitigation should not turn upon whether the ordinary or average person in the defendant's shoes would have been provoked into a heat of passion. The jury should assess whether the nature of the provoking circumstances supports mitigation and whether the motivations underlying the defendant's heat of passion are ones that the criminal law should countenance. A careful dissection of a defendant's claim of trans panic should lead the jury, in most trans panic cases, to conclude that the basis for the defendant's loss of selfcontrol is not legally adequate. Neither homophobic fear of being seen as gay, a desire to police gender norms, nor anger at the victim's alleged deceit about her biological sex should be considered legitimate bases for mitigation under the provocation defense.

Our proposals for reform may not be as direct a form of moral condemnation as a legislative ban on panic strategies, but are preferable because they leave the question as to what constitutes legally adequate 
provocation - a question that involves consideration of the facts of the case and community values - in the hands of the jury. The jury is not a perfect institution, but because it has more contextual information about the individual case before it, it is better suited than the legislature to deal with questions of culpability and whether punishment is deserved. Moreover, our proposals for reform are preferable to a legislative ban because they are aimed at raising awareness of the structures of masculinity that can lead to violence against transgender individuals. ${ }^{22}$ We seek to attack the root structures of masculinity and heteronormativity in order to combat the trans panic defense strategy in a more lasting way.

\section{TRANSGENDER}

[A] lot of people have absolutely no idea what a transgender person is or what it means.

-Elizabeth Riley ${ }^{23}$

\section{A. Terminology}

"Transgender" is an adjective used to describe individuals whose biological sex is different from the gender identity they ascribe to themselves. ${ }^{24}$ Terry Kogan explains that transgender individuals are

22. While a legislative ban would send an important message about society's condemnation of the killing of gay men and trans women, it may do little to actually deter such violence. Giovanna Shay and J. Kelly Strader make a similar point about hate crime law, writing that "hate crime statutes may send an important message, but have done little to deter violence against LGBTQ people." Giovanna Shay \& J. Kelly Strader, Queer (In)Justice: Mapping New Gay (Scholarly) Agendas, I02 J. CRIm. L. \& Criminology i7 I, I74 (2012) (reviewing Victoria L. Steinberg, A Heat of Passion Offense: Emotions and Bias in "Trans Panic" Mitigation Claims, 25 B.C. ThiRd World L.J. 499 (2005)).

23. Leslie J. Moran \& Andrew N. Sharpe, Violence, Identity and Policing: The Case of Violence Against Transgender People, 4 Crim. Justice 395, 403 (2004) (quoting Elizabeth Riley, coordinator of the Sydney Gender Centre).

24. Transgender Law Ctr., io Tips for Working with Transgender Patients i (20I i), available at http://transgenderlawcenter.org/issues/health/Iotips ("The term 'transgender' is used to describe people whose gender identity does not correspond to their birth-assigned sex and/or the stereotypes associated with that sex."); Mary Kristen Kelly, (Trans)forming Traditional Interpretations of Title VII: "Because of Sex" and the Transgender Dilemma, I7 Duke J. Gender L. \& Pol'y 219, 22 I (2010) (citing Human Rights Campaign Found., Transgender Inclusion in the WORKPLACE 2 (2008), available at http://www.hrc.org/files/assets/resources/HRC_Foundation__Transgender_Inclusion_in_the_ Workplace_2nd_Edition_-_2008.pdf) ("[T]ransgender means that a person's physiological sex is different from his or her psychological perception or expression of his or her sex."). See Dylan Vade, Expanding Gender and Expanding the Law: Toward a Social and Legal Conceptualization of Gender That Is More Inclusive of Transgender People, I I Mich. J. Gender \& L. 253, 3 I2 (2005)

("[T]ransgender people are people who have a different gender identity than the one assigned at birth and/or different gender expression then the one that is stereotypically associated with the gender assigned at birth."). Vade strongly disagrees with the conceptualization of transgender as one whose sex and gender do not match. Id. at 278. Vade prefers a definition of transgender that does not rely on 
people who feel they are trapped or imprisoned in a body that does not reflect their true gender identity. ${ }^{25} \mathrm{~A}$ transgender woman, for example, considers herself a female, even though her body is anatomically male. ${ }^{26}$

Patience Crozier notes, "American society assumes that there are two sexes, male and female, and flowing from those two sexes are two genders, masculine and feminine, and that all people fall into one of those two closely linked categories." 27 This, however, is not a completely accurate picture. As Frank Valdes explains, "[t]he first common misunderstanding ... is the equation of sex, as a physical or biological trait, with 'penis' or 'vagina.'”28

Sex is the term used to refer to one's physical or biological attributes. ${ }^{29}$ In today's society, a person with a penis is presumed to be male; a person with breasts and a vagina is presumed to be female. Transgender men, however, are born with vaginas and transgender women are born with penises and testicles.

Gender, in contrast, is the term used to refer to the way a person presents himself or herself to the world..$^{30}$ One can present as either feminine or masculine. ${ }^{3^{I}}$ Often there is congruence between one's sex and one's gender, with men presenting as masculine and women presenting as feminine, but not always. Some men are more feminine than other men in the way they act and some women are more masculine than other women in the way they dress and carry themselves. As Dylan Vade notes, "there are feminine women, masculine women, androgynous women, feminine men, androgynous men, [and] masculine men, to name just a few." 32

\footnotetext{
what he calls the sex-gender distinction and would define transgender people as "people whose birthassigned gender does not completely describe the person's self-identified gender." Id. at 3I I-I 2.

25. Terry S. Kogan, Transsexuals and Critical Gender Theory: The Possibility of a Restroom Labeled "Other", 48 Hastings L.J. I223, I225 (I997).

26. Id.

27. Patience W. Crozier, Book Note, Forcing Boys To Be Boys: The Persecution of Gender NonConforming Youth, 2i B.C. Third World L.J. I23, I25 (200I) (reviewing Christina Hoff Sommers, The War Against Boys: How Misguided Feminism is Harming Our Young Men (2000)). See also Kim D. Felsenthal, Socio-Spatial Experiences of Transgender Individuals, in 4 The Psychology of Prejudice AND Discrimination 204 (Jean Lau Chin ed., 2004) (noting that our society has constructed "a gender system that consists only of males and females, not allowing for a third, fourth, or nth gender").

28. Francisco Valdes, Queers, Sissies, Dykes, and Tomboys: Deconstructing the Conflation of "Sex," "Gender," and "Sexual Orientation" in Euro-American Law and Society, 83 Calif. L. Rev. I, 20 (I995).

29. Felsenthal, supra note 27 , at 20I-02.

30. Gender is often viewed as a social construction while sex is perceived as real. Id. at 204.

3I. Valdes notes that 'sex denotes bio-physical aspects of personhood associated with 'man' and 'woman,' while gender denotes the social constructions understood as 'male' and 'female' or 'masculine' and 'feminine." Valdes, supra note 28, at 21. See also Vade, supra note 24, at 262 (arguing that the sex-gender distinction is harmful to transgender people because it suggests that one's biological sex is one's true or real identity).
}

32. Vade, supra note 24 , at 265. 
Transgender men and women are not simply individuals who present their gender identity in a way that does not conform to their biological sex. A gay man, for example, may walk or talk in a feminine manner and may even wear effeminate clothing but still view himself as a man. A transgender woman, however, is a person born with male anatomy who self-identifies as female. Like the effeminate gay man, she may walk, talk, and dress in a feminine manner. Unlike the gay man, who sees himself as a man who is sexually attracted to other men, the transgender woman sees herself as a woman, a woman born into a man's body.

Gender identity should not be confused with sexual orientation. The transgender woman may be heterosexual (attracted to men) or lesbian (attracted to women).33 Likewise, the transgender man may be gay (attracted to men) or heterosexual (attracted to women).34 Many people assume that an individual with male anatomy who is sexually attracted to men must be gay, but a transgender woman - a female born with male anatomy-who likes men is heterosexual. Janet Mock, a transgender woman who has written about her transition, explains why a transgender girl may call herself gay for a short time:

As a tween, I was living in the murkiness of sexuality and gender. I knew I was viewed as a boy. I knew I liked boys. I knew I felt like a girl. Like many young trans people, I hadn't learned terms like trans, transgender, or transsexual-definitions that would have offered me clarity about my gender identity. For example, a trans girl who is assigned male at birth and attracted to boys may call herself gay for a short time $-\mathrm{a}$ transitional identity on her road to self-discovery. In actuality, though, since her gender identity is that of the girl, and she is attracted to boys, then her sexual orientation mirrors that of a heterosexual girl, not a gay man..$^{35}$

The words "transgender" and "transsexual" are often used interchangeably to describe individuals whose gender identity does not match the gender assigned to them at birth. ${ }^{36}$ It is increasingly common, however, for the term "transgender" to be used as an umbrella term ${ }^{37}$

33. Janet Mock, Redefining Realness: My Path to Womanhood, Identity, Love \& So Much More 50 (2014) ("A trans person can be straight, gay, bisexual, etc. ....").

34. When transgender men and lesbian women date, their relationships do not fall neatly into either of the two standard categories of heterosexual or homosexual.

35. Mock, supra note 33, at 80.

36. Noa Ben-Asher, The Necessity of Sex Change: A Struggle for Intersex and Transex Liberties, 29 Harv. J.L. \& Gender 5I, 5I n.I (2006) (noting that "frequently medical and psychological discourses read [transgender] as synonymous to "transsexual"').

37. See Paisley Currah, Gender Pluralisms Under the Transgender Umbrella, in Transgender Rights 3, 4 (Paisley Currah et al. eds., 2006) (noting that the meaning of transgender has changed over time from "signifying a subject position between cross-dresser and transsexual," to being an umbrella term for "all persons whose perceived gender and anatomic sex may conflict with [their] gender expression”); Paisley Currah \& Shannon Minter, Nat'l Ctr. for Lesbian Rights, Transgender Equality: A Handbook for Activists AND Policymakers 3 (2000), available at 
that encompasses a wide range of gender nonconforming individuals, including transvestites (men who like to wear women's clothing for erotic pleasure),${ }^{8}$ cross-dressers (men and women who dress in clothing usually worn by the opposite gender), ${ }^{39}$ and transsexuals (individuals who undergo or seek to undergo sex reassignment surgery to align their bodies with their gender identity)..$^{40}$ As Dean Spade-possibly the first openly transgender tenure-track law professor ${ }^{41}-$ explains, "[t]ransgender and trans are both political terms that have emerged in recent years to indicate a wide variety of people whose gender identity or expression transgress the rules of binary gender." 42 Many in the

http://www.thetaskforce.org/downloads/reports/reports/TransgenderEquality.pdf. (noting that "transgender has become an 'umbrella' term that is used to describe a wide range of identities and experiences, including but not limited to: pre-operative, post-operative, and non-operative transsexual people; male and female cross-dressers (sometimes referred to as 'transvestites,' 'drag queens' or 'drag kings'), intersexed individuals, and men and women, regardless of sexual orientation, whose appearance or characteristics are perceived to be gender atypical"); NAT'L CTR. FOR TRANSGENDER Equal., Transgender Terminology (Jan. 20I4), available at http://transequality.org/Resources/ NCTE_TransTerminology.pdf (noting that "transgender" is "[a] term for people whose gender identity, expression or behavior is different from those typically associated with their assigned sex at birth"). See also Kogan, supra note 25, at I 225 n.6 (noting that the term "transgender" is increasingly being used to describe both transvestites, men who like to cross-dress but have no desire to change their biological sex, and transsexuals, individuals whose internal sense of gender identity is the opposite of their physical body); Vade, supra note 24, at 255 n.2 ("I use the word transgender very broadly to refer to people whose gender identity and/or expression does or is perceived to not match stereotypical gender norms associated with their birth-assigned gender.").

38. The word "transvestites" refers to "males who have an episodic, compelling desire to wear women's clothes," often for erotic pleasure. Hasan Shafiqullah, Shape-Shifters, Masqueraders, \& Subversives: An Argument for the Liberation of Transgendered Individuals, 8 Hastings Women's L.J. 195, 196 (1997) (citing Richard Green, Spelling "Relief" for Transsexuals: Employment Discrimination and the Criteria of Sex, 4 YAle L. \& Pol'y Rev. I25, I27 (I985) (noting that unlike transsexuals, transvestites are not discontent with being male, and unlike gay men, transvestites are sexually attracted to women))

39. "Cross-dressers" are either men who dress in traditionally female clothing or women who dress in traditionally male clothing, not necessarily for the purpose of sexual arousal. Shafiqullah, supra note 38 , at 196 .

40. Susan Etta Keller, Operations of Legal Rhetoric: Examining Transsexual and Judicial Identity, 34 HaRv. C.R.-C.L. L. Rev. 329, 329 (1999) ("A transsexual is someone who undergoes or contemplates undergoing anatomical and hormonal modifications in order to live in and be recognized as a different gender than the one attributed at birth."). See NAT'L CTr. For Transgender Equal., TransGender Terminology (Jan. 20I4), available at http://transequality.org/Resources/NCTE_

TransTerminology.pdf (noting that the word "transsexual" is "[a]n older term for people whose gender identity is different from their assigned sex at birth who seek[] to transition from male to female or female to male," and that the term is disliked because it sounds overly clinical).

4I. Dean Spade, Be Professional!', 33 Harv. J.L. \& Gender 7I, 7I (20I0).

42. Dean Spade, Resisting Medicine, Re/modeling Gender, I8 Berkeley Women's L.J. I5, I6 n.2 (2003). While others might include intersex people (individuals whose biological features make it difficult to classify them as either male or female) under the transgender umbrella, we do not do so out of sensitivity to concerns expressed to us by the Chairperson of the Organisation Intersex International ("OII"). E-mail from Hida Viloria, Chairperson, Organisation Intersex International, to Cynthia Lee (Apr. 5, 2013, 8:18 PM) (on file with Cynthia Lee); E-mail from Hida Viloria, Chairperson, Organisation Intersex International, to Cynthia Lee (May 6, 2013, 5:53 PM) (on file with 
transgender community view the word transvestite as an offensive slur. 43 Similarly, many in the transgender community disfavor the term transsexual.44 The term "cisgender" (or "cis" for short) describes nontransgender individuals, that is, persons who "identify with the gender that correlates with the sex they were assigned at birth." 45

State laws addressing whether a transgender person may change the gender marker on his or her driver's license or birth certificate vary considerably. Many states will permit a change of gender marker on one's driver's license after an individual has undergone sex reassignment surgery. ${ }^{46}$ Most states will also allow the name and gender on one's birth certificate to be changed or will issue a new birth certificate if a transgender individual has undergone sex reassignment surgery. ${ }^{47}$ Both California and Vermont allow pre-operative transgender individuals to change their birth certificates and driver's licenses upon a physician's determination that an individual has received appropriate individualized treatment for gender transition..$^{8}$ Other states, such as Massachusetts, require gender reassignment surgery for birth certificate amendments, but not for amendments to driver's licenses. 49 In June 20I4, New York adopted a policy allowing transgender individuals to change the gender marker on their birth certificates without first undergoing sex reassignment surgery. $5^{\circ}$ Also in June 20I4, the American Medical Association announced their position that transgender people should not

Cynthia Lee). Intersex people are individuals born with biological features that make it difficult to clearly categorize them as either male or female. Crozier, supra note 27, at I26-27. Intersex individuals may have both male and female physical characteristics. Shafiqullah, supra note 38 . For example, an intersex individual may be born with ovaries and male genitalia. Crozier, supra note 27, at I26. According to the OII, no research has yet been conducted that would dispute the research of Dr. Anne Fausto-Sterling that at least I.9\%f live births are intersex births. On the Prevalence of Intersex and the Various Numbers Quoted for It, OII InTERSEX Network (Jan. 22, 20I2), http://oiiusa.org/259/prevalence-intersex-numbers-quoted (noting that a minimum of I.9 percent of all live births are intersex births and the actual number of intersex births is likely to be substantially higher).

43. See Resources for Journalists and Media Covering CHAZ Bono and TRANSGENDER Issues, GLAAD, http://www.glaad.org/publications/resources-journalists-and-media-covering-chaz-bono-andtransgender-issues (last visited Dec. I4, 2014).

44. Nat'L Ctr. For Transgender Equal., SUPRa note 40.

45. Моск, supra note 33, at 23.

46. Driver's License Policies by State, Nat'L CTr. For Transgender Equal., http://transequality.org/

Resources/DL/DL_policies.html (last updated Jan. 4, 20I3).

47. Changing Birth Certificate Sex Designations: State-by-State Guidelines, Lambda Legal, http://www.lambdalegal.org/publications/sources-of-authority-to-amend (last updated Jul. I4, 20I4).

48. Cal. Health \& Safety Code § I03425 (West 20I4); Vt. Stat. Ann. tit. i8, § 5 I I 2 (20I4).

49. ChanGE of GENDER, Mass. Registry of Motor Vehicles, https://secure.rmv.state.ma.us/

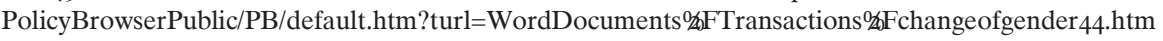
(last visited Dec. I4, 2014).

50. Jonathan Allen, New York Drops Surgery Rule for Changing Sex on Birth Certificate, Reuters, June 5, 20I4, AVAILABLE AT http://www.huffingtonpost.com/20I4/06/06/new-york-dropssurgery-rule_n_5454005.html. 
have to undergo sex reassignment surgery to change the gender marker on their birth certificates. ${ }^{\text {I }}$

Many transgender individuals report that their sense of gender misidentification began early in childhood..$^{52}$ According to Patrick Kelly, a psychiatrist with the Division of Child and Adolescent Psychiatry at Johns Hopkins Children's Center, gender solidifies between the ages of three and six. 53 Typically, it is around this age when a child "whose gender orientation is at odds with his or her biology begins expressing that disconnect." 54 Transgender children "may shower with their clothes on, so they don't have to see themselves." 55 In extreme cases, transgender girls have tried to cut off their penises..$^{56}$

The psychological literature pathologizes individuals who transgress socially accepted gender roles by calling a transgender person's discomfort with his or her biological body "gender dysphoria." 57 Until recently, the American Psychiatric Association suggested in its Diagnostic and Statistical Manual of Mental Disorders that transgender individuals suffer from "Gender Identity Disorder" ("GID"). $5^{8}$ As described by the World Health Organization, an individual with gender identity disorder will experience "a persistent and intense distress about assigned sex, together with a desire to be (or insistence that one is) of the

51. Bruce Japsen, AMA Says Transgender Patients Don't Need Surgery to Change Birth Certificate, Forbes.com (June 9, 20I4, 3:I9 PM), http://www.forbes.com/sites/brucejapsen/2014/o6/o9/ ama-says-transgender-patients-dont-need-surgery-to-change-birth-certificate.

52. Kogan, supra note 25, at I225-26. Kelly).

53. Petula Dvorak, Transgender at Five, WASh. Post, May 20, 20I2, at AI (quoting Patrick

54. Id.

55. $I d$.

56. Id.

57. Kogan, supra note 25, at 1226.

58. Crozier, supra note 27 , at I34 (noting that the term "gender identity disorder" was added to the Diagnostic and Statistical Manual of Mental Disorders in 1980); Shafiqullah, supra note 38, at 199. The addition of Gender Identity Disorder ("GID") to the Diagnostic and Statistical Manual of Mental Disorders in 1980 was "highly controversial because of assertions positing that GID was created to prevent possible behavioral manifestations of homosexuality." Felsenthal, supra note 27, at 205. As Felsenthal explains, "cross-dressing or atypical gender behavior in children, some assume, leads to homosexual adults; therefore, if a child is diagnosed with GID, then these behaviors can be 'fixed' through therapeutic intervention." Id. Trying to "fix" the sexual orientation of individuals attracted to the others of the same sex remains deeply controversial. When California passed legislation prohibiting licensed psychotherapists from trying to change the sexual orientation of gay minors in 2012, the law was met with fierce opposition from opponents. Lisa Leff, Calif. Gay Therapy Ban Sparks Competing Rulings, Seattle Times (Dec. http://seattletimes.com/html/nationworld/2019825547_apusgaytherapy.html (noting that "[t]wo federal judges in California have arrived at opposite conclusions on whether the state's first-of-its-kind law prohibiting licensed psychotherapists from trying to change the sexual orientation of gay minors violates the Constitution"). In 2013, the Ninth Circuit Court of Appeals held that the law was constitutional and the Supreme Court denied certiorari. Pickup v. Brown, 740 F.3d I208 (9th Cir. 2013) (en banc), cert. denied, I34 S. Ct. 287I (2014). 
other sex." ${ }^{99}$ Similarly, the 1994 edition of the Diagnostic and Statistical Manual of Mental Disorders provided that a person may be diagnosed as having gender identity disorder upon: (I) "evidence of a strong and persistent cross-gender identification, which is the desire to be, or the insistence that one is, of the other sex," and (2) "evidence of persistent discomfort about one's assigned sex or a sense of inappropriateness in the gender role of that sex." "60 In 2013, the American Psychiatric Association eliminated the term "gender identity disorder" from the Diagnostic and Statistical Manual of Mental Disorders and replaced that term with "gender dysphoria."

Regardless of which term is used, "gender identity disorder" or "gender dysphoria," the fact that the condition of discomfort with one's assigned sex is in the Diagnostic and Statistical Manual of Mental Disorders suggests that transgender people are not normal and that a transgender individual suffers from a mental disorder. As Dean Spade observes, by establishing gender nonconformity as a basis for mental illness, the American Psychiatric Association has invented a category of deviation with transgender persons as the ones who are deviant:

The diagnostic criteria for GID produces a fiction of natural gender in which normal, non-transsexual people grow up with minimal to no gender trouble or exploration, do not cross-dress as children, do not play with the wrong-gendered kids, and do not like the wrong kinds of toys or characters. This story is not believable. Yet, it survives because medicine produces it not through a description of the norm, but through a generalized account of the norm's transgression by gender deviants. ${ }^{62}$

It is difficult to assess the number of transgender men and women in the United States. "Transgender" is not a category found on the census form. Even if it were, it is unlikely that all of the individuals who consider themselves transgender would openly admit to this on a government form given the social stigma suffered by transgender individuals. ${ }^{63}$ Estimates of the size of the transgender population in the United States

59. World Health Org., The ICD-io Classification of Behavioural Disorders § F64.0.2 (20I0), available at http://apps.who.int/classifications/icd Io/browse/20 Io/en\#/F64.

6o. Am. Psychiatric Ass'n, Diagnostic and Statistical Manual of Mental Disorders 532-33 (4th ed. I994).

6r. Lindsey Tanner, U.S. Psychiatrists Approve Revisions to Diagnosis Manual, Wash. Post, Dec. 2, 2012, at A5.

62. Spade, supra note 42 , at 25.

63. Tarynn M. Witten \& A. Evan Eyler, Hate Crimes and Violence Against the Transgendered, i i Peace Rev. 46I, 462 (I999) ("[M]any members of the U.S. transgender community prefer to remain undetected, due to fear of adverse consequences from either the healthcare professions or society at large."); Sam Winter \& Lynn Conway, How Many Trans* People Are There? A 201 I Update Incorporating New Data, TRANSGENDER AsIA (20I I), http://web.hku.hk/ sjwinter/TransgenderASIA/ paper-how-many-trans-people-are-there.htm (last visited Dec. I4, 20I4) (noting that "many transpeople try to keep their trans status private"). 
are likely to be low because they are usually based on data regarding individuals who have undergone or are seeking sex reassignment procedures and do not include all the individuals who fall under the transgender umbrella. ${ }^{64}$ Nonetheless, the Williams Institute estimates that nearly 700,000 individuals in the United States, or 0.3\%f all adults, are transgender men and women. ${ }^{65}$ The National Center for Transgender Equality estimates that transgender men and women constitute between 0.25 and $\mathrm{I} \% \mathrm{f}$ the total population in the United States. ${ }^{66}$

Transgender persons are often grouped with gays and lesbians under the umbrella term "LGBT" (lesbian, gay, bisexual, and transgender) ${ }^{67}$ The grouping of transgender persons with gays, lesbians, and bisexuals may explain why many people mistakenly assume that violence against a transgender person is related to bias based on sexual orientation. ${ }^{68}$ The LGBT label also masks the fact that transgender individuals sometimes face hostility from within the gay and lesbian community. For example, some lesbians are hostile to transgender women because they view trans women as repressed gay men who are sexually attracted to other men but cannot accept their sexual orientation. ${ }^{69}$ These lesbians believe trans women falsely assert a female gender identity in order to achieve their goal of being with men. ${ }^{70}$ This view of transgender women, like the traditional understanding of sex and gender, aligns gender identity with biological sex.

64. Esther N. Tebbe \& Bonnie Moradi, Anti-Transgender Prejudice: A Structural Equation Model of Associated Constructs, 59 J. Counseling Psychol. 25I, 25I (20I2).

65. Gary J. Gates, Williams Inst., How Many People Are Lesbian, Gay, Bisexual, and TrANSGENDER? 6 (Apr. 20I I), available at http://williamsinstitute.law.ucla.edu/wp-content/uploads/

Gates-How-Many-People-LGBT-Apr-20I I.pdf. In 2003, the transgender population in the District of Columbia alone was about 4,00o persons. Jessica Xavier, Fact Sheet for Anti-Transgender Violence In the District of Columbia (Aug. 22, 2003), available at http://www.glaa.org/archive/2003/ Fact 20 Sheet $\% 20$ for 20 Anti-TG\%oViolence 200822 .pdf.

66. Nat'l Ctr. for Transgender Equal., Understanding Transgender: Frequently Asked Questions About Transgender People i (May 2009), available at http://transequality.org/Resources/ NCTE_UnderstandingTrans.pdf.

67. For commentary on why adding the "T" to "LGB" makes sense, see Matt Kailey, Does $T$ Belong with LGB?, Matt Kailey's Tranifesto (Sept. I4, 2009), http://tranifesto.com/2009/09/I4/doest-belong-with-glb. But see John Aravosis, How Did the T Get in LGBT?, Salon (Oct. 8, 2007, 4:Io AM), http://www.salon.com/2007/Io/08/lgbt (raising concerns and questions about whether adding the "T" to "LGB" makes sense); Brynn Tannehill, Why 'LGB' and 'T' Belong Together, The Huffington Post (Feb. 25, 2013, I0:52 AM), http://www.huffingtonpost.com/brynn-tannehill/why-lgb-and-t-belongtogether_b_27466ı6.html.

68. There is evidence that police officers often mischaracterize acts of violence against transgender people as hate crimes based on sexual orientation rather than gender identity. Moran \& Sharpe, supra note 23, at 409; Stotzer, supra note I3, at I76.

69. Kogan, supra note 25, at I 230.

70. Id. 
It is important to recognize the multidimensional identities held by transgender persons. ${ }^{71}$ Transgender men and women can be heterosexual, gay or lesbian, or bisexual. They may be wealthy, middleclass, working class, or at the bottom of the socio-economic ladder. ${ }^{72}$ They may be White ${ }^{73}$ or belong to a racial or ethnic minority group.

\section{B. Violence Against Transgender Persons}

The moment of forced disclosure is a hostile one to experience, one in which many trans women, even those who have the conditional privilege of 'passing' that I have, can be victim to violence and exiling.

\section{- Janet Mock ${ }^{74}$}

Transgender men and women are harassed, assaulted, and killed at alarming rates.75 Assessing the true extent of violence against transgender people is difficult because, until recently, there was no nationwide effort to collect statistics on crimes motivated by gender identity bias. Numerous attempts to add gender and gender identity to the list of bias categories protected under the Hate Crimes Statistics Act

7I. As Leslie Morgan and Andrew Sharpe note, "it is necessary for interventions to recognise [sic] the many differences between transgender people, differences that run along axes of race, ethnicity, class, age and sexuality, as well as differences between transgender women and transgender men...." Leslie J. Moran \& Andrew N. Sharpe, Policing the Transgender/Violence Relation, i3 Current Issues Crim. Justice 269, 28I (2002). See Darren Lenard Hutchinson, Identity Crisis: "Intersectionality," "Multidimensionality," and the Development of an Adequate Theory of Subordination, 6 Мich. J. RACE \& L. 285, 3I4 (200I) (arguing for a multidimensional equality theory that would be more responsive to the needs of transgender people); Peter Kwan, Jeffrey Dahmer and the Cosynthesis of Categories, 48 Hastings L.J. I257, I264 (1997) (developing a theory of "cosynthesis" that replaces current conceptualizations of race, gender, and sexual orientation as separate categories with a theory that allows their simultaneous implication).

72. Many transgender persons are unemployed because of discrimination they suffered when they transitioned or became open about their gender identity. Jaime M. GRANT ET AL., NAT'L CTR. For Transgender Equal. \& Nat'l Gay and Lesbian Task Force, Injustice at Every Turn: A Report of the National Transgender Discrimination Survey 5I (20II), available at http://www.thetaskforce.org/downloads/reports/reports/ntds_full.pdf (noting that "[f]orty-seven percent ( $47^{\circ} \%$ [of those surveyed] said they had experienced an adverse job outcome, such as being fired, not hired or denied a promotion because of being transgender/gender non-conforming; $26 \% \mathrm{of}$ respondents said that they had lost a job due to being transgender or gender non-conforming").

73. I purposely capitalize the word White to emphasize the fact that Whiteness is a socially constructed racial category. See, e.g., Angela Onwuachi-Willig, Celebrating Critical Race Theory at 20, 94 Iowa L. Rev. I497, I500 n.I I (2009) (explaining author's choice to capitalize Black and White when used as nouns to describe racial groups, but not when used as adjectives). See also Cheryl I. Harris, Whiteness as Property, I06 Harv. L. Rev. I707, I716-I8 (1993) (arguing that whiteness was in part a social construct designed to differentiate free whites from enslaved blacks); Martha R. Mahoney, Segregation, Whiteness, and Transformation, I43 U. PA. L. Rev. I659, I660 (I995) (arguing "race is a social construction in which whiteness is a distinct, socially constructed identity").

74. МоCK, SUPRA note 33, at 247. By "passing," Mock means being able to pass as an individual who was born with female anatomy, not having her female gender identity questioned.

75. Spade, supra note $4 \mathrm{I}$, at 78 n.I 2. 
were unsuccessful until recently. ${ }^{76}$ In 2012, Congress finally passed the Matthew Shepard and James Byrd, Jr., Hate Crimes Prevention Act of 2009, which amended the Hate Crimes Statistics Act to include bias based on gender and gender identity. ${ }^{77}$ No federal government statistics on hate crimes based on gender identity, however, were available at the time this Article was written. ${ }^{78}$ While twelve states and the District of Columbia prohibit hate crimes based on actual or perceived gender identity, 79 hate crimes against transgender individuals may be significantly underreported because gender identity bias is often mischaracterized as bias on the basis of sexual orientation..$^{80}$

While government data on violence against transgender persons is limited, a few private organizations have begun collecting data on antitransgender violence. For example, the International Transgender Day of Remembrance Project, sponsored by Gender Education and Advocacy and authored by Gwendolyn Ann Smith, reported in November 20I I that over 330 transgender murders had occurred in the United States since $1970 .{ }^{81}$ This comes to an average of six or seven murders involving trans victims each year, or one murder every two months, over the last four decades. Reports from the National Coalition of Anti-Violence Programs ("NCAVP") suggest that the number of transgender victims of murder has increased significantly in the last few years. According to the NCAVP, thirteen transgender individuals, all transgender women of color, were murdered in $2012,{ }^{82}$ twelve

76. See Stotzer, supra note I3, at 177 (noting that "in 2007 both the House and Senate passed versions of a hate crime law, called the Matthew Shepard Act, that would have mandated the FBI to count transgender hate crimes in the United States as they counted those based on race, ethnicity, sexual orientation, religion, and disability" but both House and Senate versions of the bill were unsuccessful).

77. 28 U.S.C. $\S 534$ (2014).

78. The FBI is implementing mechanisms to collect data on crimes motivated by gender and gender identity bias. HATE CRIMES Remain STEADY: zoIo FBI RePort RELEASED, Fed. Bureau of InVESTIGATION (Nov. I4, 20I I), http://www.fbi.gov/news/stories/20I I/november/hatecrimes_I I I4I I.

79. Cal. Penal Code $\$ \S 422.55,422.56$ (West 20I4); Colo. Rev. Stat. $§$ i8-9-i2 I (20I4); Conn. Gen. Stat. § 53a-I8Ij (20I4); D.C. Code §§ 22-370I, 22-3702 (20I4); Haw. Rev. Stat. § 846-5I (20I4); MD. Code Ann., Educ. §7-424 (LexisNexis 20I4); Minn. Stat. §§ 363A.03(44), 609.223I(4), 609.595(Ia), 6i iA.79 (20I4); Mo. Rev. Stat. § 557.035 (20I4); N.J. Stat. Ann. § 2C:I6-I (West 20I4); N.M. Stat. AnN. §3I-I8B-3 (20I4); Or. Rev. Stat. §§ i66.I55, I66.I65 (20I4); Vt. Stat. Ann. tit. I3, $\S \S$ I455, I458 (20I4); Wash. Rev. Code § 9A.36.080 (20I4). See Jim O’Hara, Dwight DeLee Gets the Maximum in Transgender Slaying, Syracuse.com (Aug. I8, 2009, I2:00 PM), http://www.syracuse.com/news/index.ssf/2009/08/dwight_delee_to_be_sentenced_i.html; Jim Spellman, Transgender Murder, Hate Crime Conviction a First, CNN (Apr. 23, 2009), http://www.cnn.com/2009/ CRIME/o4/22/transgender.slaying.trial/index.html.

80. Moran \& Sharpe, supra note 23, at 409 ("the tendency to translate a trans incident to one of homophobia [might be attributed to a] lack of understanding"); Stotzer, supra note 13, at 176.

8i. All Years to 20 i i, Int'L Transgender Day of Remembrance, http://tdor.info/?attachment $\mathrm{id}=22 \mathrm{I} 6$ (last updated Nov. I0, 20I I).

82. Nat'l Coal. of Anti-Violence Programs, Lesbian, Gay, Bisexual, Transgender, Queer AND HIV-AfFected Hate Violence in 20I2, at 8 (2013), available at http://www.avp.org/storage/ 
transgender persons were murdered in $20 \mathrm{II},{ }^{83}$ twelve transgender persons were murdered in $2010,{ }^{84}$ and eleven transgender persons were murdered in 2009. These statistics indicate that an average of one transgender murder occurs each month. ${ }^{85}$ Professor Spade estimates that the murder rate of transgender persons is I7 times higher than the murder rate of non-transgender individuals. ${ }^{86}$ The Human Rights Campaign estimates that one out of every $\mathrm{I}, 000$ homicides in the United States is an anti-transgender hate crime. ${ }^{87}$

In addition to facing the threat of being killed because of their gender identity, transgender persons are assaulted at alarming rates. In an in-depth study of types of violence experienced by a sample of 402 transgender persons across the United States, Emilia Lombardi and others found that close to half of the sample population (forty-seven percent) had been assaulted because of their transgender status at some point during their lives. ${ }^{88}$ In other words, one out of every two transgender individuals is likely to be physically attacked at some point in his or her lifetime because of his or her transgender status.

In its most recent reports, the NCAVP found that approximately $43 \mathrm{I}$ transgender persons were the victims of hate violence in $2010^{89}$ and approximately 37I transgender persons were the targets of hate violence in 2009. ${ }^{90}$ These statistics suggest that each month, between thirty to

documents/ncavp_20I2_hvreport_final.pdf (noting that transgender women accounted for fifty percent of the twenty-five lesbian, gay, bisexual, transgender, queer, and HIV-affected ("LGBTQH") murder cases).

83. Nat'l Coal. of Anti-Violence Programs, Hate Violence Against Lesbian, Gay, Bisexual, Transgender, Queer, and HIV-Affected Communities in the United States in 20i i, at 45 (20I2), available at http://www.avp.org/storage/documents/Reports/20I2_NCAVP_20II_HV_Report.pdf (noting that transgender women accounted for forty of the thirty LGBTQH murder cases).

84. Nat'l Coal. of Anti-Violence Programs, Hate Violence Against lesbian, Gay, Bisexual, Transgender, Queer, and HIV-Affected Communities in the United States in 20io, at 7 (20II), available at http://www.avp.org/storage/documents/Reports/20II_NCAVP_HV_Reports.pdf (noting that transgender women accounted for forty-four percent of the twenty-seven LGBTQH murder cases).

85. Nat'l Coal. of Anti-Violence Programs, Hate Violence Against the Lesbian, Gay, Bisexual, Transgender, and Queer Communities in the United States in 2009, at 32 (2010), available at http://www.avp.org/storage/documents/Reports/2009_NCAVP_HV_Report.pdf (noting that transgender women accounted for fifty percent of the twenty-two hate murder cases).

86. Spade, supra note $4 \mathrm{I}$, at 78 n.I 2.

87. How Do Transgender People Suffer from Discrimination?, Human Rights Campaign, available at http://web.archive.org/web/20I I07101925I2/http://www.hrc.org/issues/I508.htm (last visited Dec. I4, 2014).

88. Emilia L. Lombardi et al., Gender Violence: Transgender Experiences with Violence and Discrimination, 42 J. Homosexuality 89, 95 (200I).

89. Transgender, gender nonconforming (self-identified, genderqueer, and questioning), and intersex persons represented a combined I7.2\% all reports of anti-LGBTQH hate violence in 2010. Nat'l CoAl. of Anti-Violence Programs, supra note 84, at 25. NCAVP gathered information on 2,503 LGBTQH survivors and victims in 2010. Id. at I7. This percentage amounts to approximately $43 \mathrm{I}-$ the number of transgender and non-gender conforming victims of hate violence in 2010.

90. NCAVP found that 2,I8I LGBTQH persons were the victims of hate violence in 2009. NAT'L Coal. of Anti-Violence Programs, supra note 85, at i6. Transgender and gender nonconforming 
thirty-six transgender persons are the victims of hate violence in the United States. In other words, each day, somewhere in the United States, a transgender person is subjected to a violent attack because of his or her gender nonconformity.

Race and class often interact with gender identity in ways that mark low-income transgender persons of color as the ones most at risk of becoming victims of an assault. In one study of violence against transgender individuals in Los Angeles County from 2002 to 2006, Rebecca Stotzer found that transgender persons were rarely attacked "solely because of their gender identity; a host of other dimensions, including race, came into play as well."9r Stotzer's study revealed that transgender victims of hate violence were disproportionately African American" and that "[t]ransgender people at the bottom of the socioeconomic ladder [were] more likely to be victims of violence." 93 Stotzer concluded that transgender persons may be targets of violence because they are stereotyped as easy targets. 94 Reports from the NCAVP, which began collecting data on attacks against transgender people in 1998 , echo Stotzer's findings. ${ }^{95}$ The NCAVP found that, of all the victims of anti-LGBTQ violence, transgender persons and people of color were the most likely to be the victims of hate violence. ${ }^{6}$

\section{Provocation and Trans Panic}

What I think is a problem is that these transgenders lie and say they're women to get with some man, and then he's got to beat them up.

- Anonymous $^{97}$

individuals constituted seventeen percent of the total number of LGBTQH persons who were the victims of hate violence in 2009. Id. at I7 (noting that transgender women accounted for approximately eleven percent of those reporting and transgender men, those with intersex conditions, and people identifying as self-identified or other, genderqueer, or questioning, accounted for six percent of reports in 2009). Seventeen percent of 2,I8I is $37 \mathrm{I}$.

9I. Rebecca L. Stotzer, Gender Identity and Hate Crimes: Violence Against Transgender People in Los Angeles County, 5 Sexuality Res. \& Soc. Pol'y 43, 50 (2008).

92. Id. at 46 .

93. Id. at 50; Shay \& Strader, supra note 22 , at I8o (noting that the media pays less attention to victims that are economically underprivileged, transgender, or people of color).

94. Stotzer, supra note 9I, at 47.

95. Nat'l Coal. of Anti-Violence Programs, Anti-Lesbian, Gay, Bisexual and Transgender VIOLENCE IN I998, at I9 (I999), available at http://www.avp.org/storage/documents/Reports/I998_NCAVP_

Bias_Report.pdf (reporting I 48 cases of violence against transgender women and 13 cases of violence against transgender men for a total of I6I cases of hate violence against transgender victims).

96. Nat'l Coal. of Anti-Violence Programs, supra note 85, at 7.

97. Interview by Professor Gabriel Arkles with Anonymous Training Attendee, Transgender Awareness for Service Providers, in L.A., Cal. (Feb. 8, 2013). 


\section{A. The Doctrine of Provocation}

The defense of provocation, also known as the heat of passion defense, is a partial defense to murder..$^{9}$ If the jury finds that the defendant was provoked into a heat of passion by legally adequate provocation, it may find the defendant not guilty of murder, the charged offense, and instead find the defendant guilty of voluntary manslaughter, a less serious form of homicide. ${ }^{99}$ Alternatively, the jury may mitigate in favor of the defendant by rejecting a charge of first-degree murder, finding the defendant guilty of only second-degree murder. ${ }^{\text {Ioo }}$

At early common law, not all forms of provocation had this mitigating legal effect. Courts recognized only limited categories of legally adequate provocation. A murder defendant could claim provocation only if he had: (I) suffered an extreme assault or battery, (2) been engaged in mutual combat with the victim, (3) observed the victim committing a serious felony against a close relative, (4) been illegally arrested, or (5) caught his wife in the act of adultery. ${ }^{\text {Ior }}$ These five categories were the only ways a defendant could mitigate a murder charge down to manslaughter, and reflected what constituted legally adequate provocation at early common law. ${ }^{\mathrm{I} 2}$ The early common law approach was problematic because it was very rigid. A defendant could not claim the provocation mitigation unless he fell strictly within one of the categories of legally adequate provocation. The early common law approach was woefully insensitive to context.

Eventually, the early common law approach was abandoned in favor of a more flexible, context driven approach. Today, most jurisdictions utilize a "reasonable person" approach to provocation. ${ }^{103}$ Under the

98. Provocation is a partial defense, not a complete defense, because the defendant who successfully argues provocation is not fully absolved of criminal liability. The defendant is merely acquitted of the charged offense but convicted of a lesser offense. See Dressler, SUPRA note I4, at \$3 I.07(A).

99. SEE id; see also, Del. Code AnN. tit. II, $\$ 632$ (2014) ("A person is guilty of manslaughter when ... [t] he person intentionally causes the death of another person ... under the influence of extreme emotional disturbance."); TenN. Code AnN. §39-I3-2II(a) (2014) ("Voluntary manslaughter is the intentional or knowing killing of another in a state of passion produced by adequate provocation sufficient to lead a reasonable person to act in an irrational manner.").

ioo. See, e.g., 720 Ill. Comp. Sтат. 5/9-2 (20I4) ("A person commits the offense of second-degree murder when he or she commits the offense of first-degree murder ... [and] at the time of the killing he or she is acting under a sudden and intense passion resulting from serious provocation by the individual killed...."); WIS. STAT. § 939.44(2) (2014) ("Adequate provocation is an affirmative defense only to firstdegree intentional homicide and mitigates that offense to 2nd-degree intentional homicide.").

IOI. DRESSLER, supra note I4, at $\S_{3}$ I.O7(B)(2)(a).

io2. Cynthia Lee, Murder and the Reasonable Man: Passion and Fear in the Criminal COURTROOM I9 (2003).

I03. Id. at 25. Some jurisdictions have adopted the Model Penal Code's extreme emotional disturbance defense, which allows a defendant who kills while suffering from an extreme mental or emotional disturbance for which there is a reasonable explanation or excuse to be convicted of manslaughter rather than murder. Model Penal Code § 2 I0.3(I)(b) (200I). Under the Model Penal 
modern test for provocation, the jury may find a defendant charged with murder guilty of the lesser included offense of voluntary manslaughter if it finds that: (I) the defendant was actually provoked into a heat of passion, (2) the reasonable person in the defendant's shoes would have been provoked, (3) the defendant did not have time to cool off, and (4) the reasonable person would not have cooled. ${ }^{104}$

The provocation defense is based on the idea that certain extreme circumstances might cause the average person to lose his or her selfcontrol and react in a fatally violent way. ${ }^{105}$ If the provoked killer's loss of self-control is something that an ordinary person in the same situation might experience, the provoked killer is considered less culpable than the average intentional killer, and therefore deserving of some mitigation. ${ }^{106}$ The difficult question is usually thought to be which characteristics of the defendant ought to be incorporated into the reasonable person standard to ensure a fair assessment of the defendant's culpability. This is the wrong question to ask. As Peter Westen argues, the key question in provocation cases is not to what extent the idealized reasonable person should be individualized with the defendant's traits, but rather whether the defendant's "inadvertence or extreme emotional agitation ... manifests appropriate respect on his part for the interests of others." I07 Similarly, Kyron Huigens observes that provocation is less a question regarding the capacity of the defendant to conform his conduct to the law and more a question of whether the defendant has lived up to normative expectations. ${ }^{108}$ Accordingly, the question jurors should be asking when evaluating whether a defendant's claim of provocation should be accepted is whether the defendant's loss of self-control was normatively appropriate, not whether the average person in the defendant's shoes would have lost his self-control.

The provocation doctrine is usually viewed as a partial excuse rather than a partial justification. ${ }^{109}$ The law mitigates not because society

Code's test, the reasonableness of the explanation or excuse is to be viewed from the defendant's perspective, not the perspective of an ordinary or typical person. Id:; see also Paul H. Robinson, Murder Mitigation in the Fifty-Two American Jurisdictions: A Case Study in Doctrinal Interrelation Analysis, 47 Tex. Tech L. Rev. (forthcoming 20I4) (noting that 40 states currently use the modern test for provocation and only twelve states have adopted the Model Penal Code's extreme emotional disturbance defense).

I04. DressLer, supra note I4, at § 3I.07(A); LEE, supra note I02, at 25.

I05. Dressler, supra note I4, at § 3I.07(B)(2)(b)(i).

I06. Id.

I07. Peter Westen, Individualizing the Reasonable Person in Criminal Law, 2 Crim. Law \& PhIL. I37, I40 (2008).

I08. Kyron Huigens, Provocation at Face Value, 95 Marq. L. Rev. 409, 440-42 (20I I) (arguing that provocation should be looked at in terms of normative expectations).

I09. SEE Dressler, supra note I4, at $\$ 3$ I.07(C)(I)-(2). In the criminal law context, a justification defense suggests the defendant did the right thing or acted the way society would have wanted him to act. Id. at $\$ 23.04(\mathrm{~B})$. An excuse, in contrast, implies that the defendant did not do the right thing, but is not morally blameworthy or at least less morally blameworthy because of some excusing condition like a 
considers the provoked killer as having done the right thing, but because it sees the defendant as less guilty than an unprovoked killer. ${ }^{110}$ The defense is better viewed as one that includes features of both excuse and justification. ${ }^{I I I}$ To the extent the doctrine mitigates culpability due to the defendant's loss of self-control, it functions as an excuse. The doctrine recognizes that the defendant who cannot control his actions is less morally blameworthy than the defendant who kills intentionally. But this explanation is not wholly satisfactory. Many killers who claim they were provoked fully intended to kill their victims. ${ }^{\mathrm{II}}$ To say that they are less morally blameworthy than the defendant who kills intentionally does not seem adequate as an explanation for the mitigation they receive. The provoked killer will often claim that the victim did something that provoked him into killing, suggesting that the victim was at least partially at fault for her own demise. ${ }^{\mathrm{II} 3}$ In this sense, the provocation defense operates as a partial justification because its success turns on the extent to which the fact finder agrees with the defendant that the victim was partially responsible for the circumstances leading to her death. ${ }^{\mathrm{II}}{ }^{4}$ Our recognition of the justificatory aspects of the provocation defense should not be interpreted as support for viewing provocation as a partial justification. We do not think it is right for a defendant claiming provocation to blame the victim. Nonetheless, this is a fairly common feature of provocation cases, suggesting that in its application, the provocation defense operates as a partial justification and partial excuse.

\section{B. Gay Panic}

In the late ig6os, male defendants charged with murdering gay men began using gay panic defense strategies. ${ }^{115}$ The defendant claiming gay panic would argue either that the victim's unwanted sexual advance provoked him into a heat of passion or that it caused him to go

\footnotetext{
mental disease or defect. Id:; Reid Griffith Fontaine, Adequate (Non)provocation and Heat of Passion as Excuse, 43 U. Мich. J.L. Reform 27, 42 (2009) (arguing that the heat of passion defense "must be understood as a partial excuse"). But see Susan D. Rozelle, Controlling Passion: Adultery and the Provocation Defense, 37 Rutgers L.J. I97, 2 I7 (2005) ("If the provocation doctrine is to remain in our criminal law jurisprudence in any form, it must find its home as a justification, rather than as an excuse."). I IO. DRESSLER, Supra note $\mathrm{I} 4$, at $\S 3 \mathrm{I} .07(\mathrm{C})(2)(\mathrm{b})$.

III. LEE, SUPRA note IO2, at 227-29 (discussing the justificatory nature of the provocation defense).

I 2. For example, the man who finds his wife in bed with another man and kills the lover may fully intend to end the man's life. By invoking the provocation defense, the defendant is arguing not that he lacked the intention to kill, but that what he did was understandable.

I I3. For example, a male defendant who argues provocation after killing a gay man suggests that his victim was to blame for unwisely making an unwanted sexual advance upon a heterosexual man.

I I4. LEE, SUPRA note I02, at 229 ("Underlying many provocation claims is the idea that the victim got what he or she deserved.").

I I5. See People v. Rodriguez, 64 Cal. Rptr. 253, 255 (Cal. Ct. App. I967); see also Lee, supra note 3 , at $49 \mathrm{I}$.
} 
temporarily insane. ${ }^{116}$ There are no precise statistics on how often gay panic has been asserted as a defense, but some estimate that defendants claimed gay panic in approximately 200 cases between 1996 and $2006 .{ }^{117}$

One of the earliest uses of gay panic came in a case famous not because the defendant used a gay panic defense, but because the case reinforced the well-established principle that the prosecution bears the burden of proving every element of the charged offense beyond a reasonable doubt. ${ }^{\mathrm{II}}$ In Mullaney $v$. Wilbur, the defendant who was charged with murdering Claude Hebert in Hebert's hotel room claimed he "attacked Hebert in a frenzy provoked by Hebert's homosexual advance."II9 The defense argued that the jury should find Wilbur not guilty of murder because he lacked criminal intent or that, at most, he should be found guilty of manslaughter since the killing occurred in the heat of passion and he was provoked by the victim's homosexual assault. ${ }^{20}$ Under Maine law, a defendant arguing provocation bore the burden of proving by a preponderance of the evidence that he acted in a heat of passion. ${ }^{21}$ The Supreme Court held that placing the burden of proving heat of passion on the defendant violated the due process requirement that the government bears the burden of proving beyond a reasonable doubt every fact necessary to constitute the crime charged. ${ }^{\mathrm{I} 22}$ As a result, the Court concluded that the State could not shift this burden to the defendant by requiring him to prove he was provoked into a heat of passion.

Gay panic continued to be used as a defense strategy from time to time in cases throughout the I970s and I980s. The defense gained national prominence when it was asserted in the Matthew Shepard case in 1999. ${ }^{123}$ Shepard, an openly gay undergraduate student at the University of Wyoming, was brutally beaten to death and tied to a wooden fence by Aaron McKinney and Russell Henderson in October

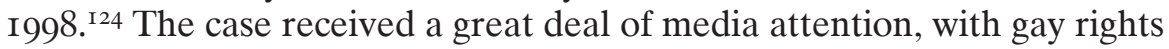
groups denouncing the brutal killing as the murder of an innocent gay

I I6. Dressler, supra note 9, at 758; Lee, supra note 3, at 49I, 500; Mison, supra note 9, at i6o.

I 7. Yomi S. Wronge, Bill Aims to Block 'Panic Defense'-Proposal Is Named for Transgender Teen, S.J. Mercury News, Jan. I6, 2006, at A2 ("There are no solid statistics on how many defendants use the panic defense, but opponents estimate there have been about 200 cases in the past decade.").

I I8. Mullaney v. Wilbur, 42 I U.S. 684, 704 (I975).

I I9. Id. at 685 .

I 20. Id.

I2I. Id. at 703

I22. The Supreme Court's jurisprudence on the question of which party bears the burden of proof has not been consistent. In Patterson v. New York, 432 U.S. I97 ( I977), just two years after Mullaney v. Wilbur, 42 I U.S. 684, the Court upheld a statute placing the burden of proving extreme emotional disturbance - the Model Penal Code's version of the provocation defense - on the defendant.

I23. Lee, supra note 3 , at 523 .

I24. Id. Henderson pled guilty to murder to avoid the death penalty. Jim Hughes, Plea SelfServing, Lawyer Says Shepard Assailant Stays Off Death Row, Denv. Post, Apr. 7, I999, at B-o I. 
man. At McKinney's trial, his attorneys argued that Shepard was at fault for provoking McKinney into a heat of passion because Shepard grabbed McKinney's crotch and tried to lick McKinney's ear while in McKinney's pickup truck. ${ }^{\mathrm{I} 25}$ The jury, however, rejected the defense's attempt to mitigate the murder charge to manslaughter, finding McKinney guilty of felony murder. ${ }^{\mathrm{I} 26}$

Five years after he was convicted, McKinney admitted, in a jailhouse interview with 20/20's Elizabeth Vargas, that he lied when he claimed Shepard made these sexual advances. ${ }^{127}$ 20/20's investigation into the murder revealed other facts that called McKinney's claim of gay panic into question. For example, in a recently published book about the killing of Matthew Shepard, Stephen Jimenez, the investigative journalist who worked with Elizabeth Vargas on the 20/20 investigation, reported that McKinney was a frequent visitor of gay bars and engaged in sex with other men long before he killed Shepard. ${ }^{\mathrm{I} 2}$ If true, this would undermine McKinney's claim that he found Shepard's alleged sexual advance upsetting because it came from a man.

The gay panic defense strategy was again utilized in a case out of Oxnard, California, in which fourteen-year-old Brandon McInerney shot and killed his fifteen-year-old classmate Larry King on February I2, 2008. ${ }^{22}$ King was a gender-nonconforming student at E.O. Green Junior High, ${ }^{130}$ who, in January 2008 , began going to school wearing lipstick and high heels. ${ }^{13 \mathrm{I}}$ In media reports about the case, King was described as an openly gay teen. ${ }^{132}$ The fact that King liked to wear makeup and high

I25. Lee, supra note 3, at 523-24; see Patrick O'Driscoll, Lawyer: Panic Drove Defendant, USA TodAY, Oct. 26, 1999, at A6 (noting that McKinney's lawyer claimed McKinney blacked out with rage after Shepard grabbed his crotch and licked his ear as they headed out of town).

I26. Tom Kenworthy, 2nd Man Is Convicted of Killing Gay Student; Wyo. Jury Weighs McKinney's Fate, WASH. Post, Nov. 4, I999, at Ai (noting that the jury of seven men and five women found McKinney guilty of felony murder, kidnapping and aggravated robbery).

I27. 20/20: The Matthew Shepard Story: Secrets of a Murder (ABC television broadcast Nov. 26, 2004) (McKinney admitted that the gay panic argument was something he and his lawyers made up because they thought it would be the best way to prove McKinney did not intend to kill Shepard).

i28. Stephen Jimenez, The Book of Matt: Hidden Truths About the Murder of Matthew SHEPARD 29 (2013).

I29. Catherine Saillant, Mistrial in Killing of Gay Student, L.A. Times, Sept. 2, 20I I, at AAI [hereinafter Saillant, Mistrial in Killing]; Catherine Saillant, Trial in Killing of Gay Teen Will Test New Law, L.A. Times, July 2I, 20I I, at AAi [hereinafter Saillant, Trial in Killing of Gay Teen]. For an excellent analysis of this case, see Strader et al., supra note 9.

I30. Ramin Setoodeh et al., Young, Gay and Murdered, Newsweek, July 28, 2008, at 4I. Just before he was shot, King told a female classmate that he was planning to change his name from Larry to Leticia. Steve Chawkins, Gay Student Shooting: 'I Wanted To Kill Him,' Accused Told Expert, L.A. Times Blog (Aug. I5, 201 I, I:58 PM), http:/latimesblogs.latimes.com/lanow/201 I/o8/gay-studentshooting-i-wanted-to-kill-him-accused-told-expert.html.

I3I. Setoodeh et al., supra note I30, at 43.

132. Catherine Saillant \& Richard Winton, Retrial in Gay Youth's Shooting to Omit Hate Allegation, L.A. Times, Oct. 6, 201 I, at Ai. 
heels and was planning to change his name from Larry to Leticia, however, suggests that King was actually a transgender female, not a gay male. ${ }^{133}$

According to the defense, a few days before the shooting, King was playing a game with a group of friends in which each participant had to approach someone and ask them to be their Valentine. ${ }^{134}$ King allegedly walked up to McInerney, who was playing basketball nearby, and asked McInerney, in front of McInerney's friends, to be his Valentine. ${ }^{135}$ McInerney's friends started teasing McInerney, saying McInerney and King were going to make "gay babies" together. ${ }^{136}$

The day before the fatal shooting, while passing McInerney in the hall, King allegedly blew a kiss at him and said something like, "What's up, baby?"I37 Later that day, McInerney told one of King's friends to say goodbye to King because she would never see him again. ${ }^{13^{8}}$ The next day, McInerney brought a .22 caliber handgun to school. ${ }^{139}$ Upon hearing King tell a female classmate that he had changed his name from Larry to Leticia, McInerney took out the gun, which he had hidden in his backpack, and shot King twice in the back of his head. ${ }^{140}$

At McInerney's murder trial, his attorneys argued that King's repeated sexual taunts provoked him into a heat of passion and, therefore, he should be found guilty of voluntary manslaughter, not murder. ${ }^{\text {I4I }}$ The government asserted that McInerney shot King in cold blood and should be found guilty of first-degree murder. ${ }^{142}$ Jurors at McInerney's trial could not come to an agreement, with seven in favor of voluntary manslaughter and five favoring murder. ${ }^{\mathrm{I} 33} \mathrm{As}$ is common when a jury hangs, the judge declared a mistrial. Before he could be retried,

I33. In "Valentine Road," a documentary about the case, one of King's friends says Larry was a transgender teen. VALENTINE RoAD (Bunim-Murray Productions \& Eddie Schmidt Productions 20I3).

I34. Strader et al., supra note 9, at I I (noting that forensic psychologist Donald Hoagland testified McInerney told him King came onto the basketball court, interrupted the game, and asked to be McInerney's valentine); Setoodeh et al., supra note I30, at 45 .

I35. Setoodeh et al., supra note i30, at 45.

I36. Id. No witnesses at McInerney's trial, however, testified that they actually saw this exchange between King and McInerney. Strader et al., supra note 9, at II.

I37. Setoodeh et al., supra note I30, at 45-46.

I38. Id.

I39. $I d$.

I40. $I d$.

I4I. Id.

I42. Strader et al., supra note 9, at 35 ("Brandon McInerney was charged with first-degree murder, which required the jury to find that McInerney acted willfully (intentionally) with premeditation and deliberation.").

I43. Catherine Saillant, Gay Teen's Killer Takes 2I-Year Deal, L.A. Times, Nov. 22, 20I I, at AAI ("McInerney's first trial ended in a hung jury in early September, with jurors torn between murder and manslaughter."); Mistrial Declared in Killing of Gay California Student, CNN (Sept. 8, 20I I, 5:44 AM), http://www.cnn.com/20I I/CRIME/og/or/california.gay.student.murder/index.html ("[T]he ninewoman, three-man jury panel said its last vote resulted in seven in favor of finding the defendant guilty of voluntary manslaughter.”). 
McInerney pled guilty to second-degree murder and voluntary manslaughter and agreed to serve twenty-one years in prison, in addition to the approximately four years he had already served prior to the plea bargain. ${ }^{\text {I4 }}$

McInerney's assertion of the gay panic defense resonated with seven of the twelve jurors who felt McInerney did not deserve to be convicted of murder. ${ }^{145}$ The fact that a majority of the jurors sympathized with McInerney's claim was surprising given the strong evidence of premeditation and deliberation. McInerney admitted to the psychiatrist who interviewed him after his arrest that he thought about killing King in advance. ${ }^{146}$ McInerney told the psychiatrist that King's comments bothered him so much that he decided to kill King. ${ }^{\text {I47 }}$ McInerney brought a loaded gun to school and concealed it in his backpack. ${ }^{{ }^{48}}$ Moreover, as Kelly Strader notes, McInerney lied to his teacher about being finished with his assignment in order to be moved to the chair near the drinking fountain, which was directly behind King. ${ }^{\mathrm{I} 9}$ McInerney stared at the back of King's head for twenty minutes before he fired the first shot. ${ }^{150}$ He shot King not once, but twice, in the back of the head and fired the second shot after the teacher in the room heard the first shot, looked at McInerney, and asked him "what the hell he was doing." I5I All of these acts suggest that McInerney thought about killing King before he pulled the trigger, and that he did so with calm, cool reflection and deliberation. ${ }^{152}$

I44. See Conversation between Cynthia Lee and Maeve Fox, Senior Deputy Dist. Att'y, Ventura Cnty. Dist. Att'y Office (Feb. I0, 20I4); see also Saillant, supra note I43. Apparently the plea deal was to ensure that McInerney would have a murder conviction on his record. Conversation between Cynthia Lee and Maeve Fox, supra. In exchange for his plea of guilty, McInerney will be paroled at age 39. Id.

I45. Saillant, Mistrial in Killing, supra note I29 ("Jurors deadlocked 7 to 5 in favor of voluntary manslaughter in the emotional two-month trial ...."); Saillant, SUPRA note I43 ("McInerney's first trial ended in a hung jury in early September, with jurors torn between murder and manslaughter."); Mistrial Declared in Killing of Gay California Student, SUPRA note I43 ("[T]he nine-woman, three-man jury panel said its last vote resulted in seven in favor of finding the defendant guilty of voluntary manslaughter.").

I46. Steve Chawkins, Psychologist Says Teen 'Snapped' and Fatally Shot Student, L.A. Times, Aug. I6, 20II, at AAI. The jurors may have also sympathized with McInerney given his age-he was I4 years old when he shot King.

I47. Chawkins, supra note I30.

I48. Calif. Teen Brandon McInerney Sentenced to 2 I Years for Point-Blank Murder of Gay Classmate, CBS News (Dec. I9, 20I I, I0:I7 PM), http://www.cbsnews.com/news/calif-teen-brandonmcinerney-sentenced-to-2I-years-for-point-blank-murder-of-gay-classmate.

I49. Strader et al., supra note 9, at I3-I4 (citing interview with Assistant Principal Joy Epstein, noting that when a student was finished with her assignment that student would be moved to a chair near the drinking fountain so that someone else could use the computer and that the seat by the drinking fountain was the seat directly behind King).

I50. Id. at I3 (citing interview with Detective Dan Swanson in Valentine Road).

I5I. Yomi S. Wronge, Two Found Guilty in Slaying of Teen-Mistrial Declared for Other Defendant in Transgender Case, S.J. Mercury News, Sept. I3, 2005, at A I.

I52. Strader et al., supra note 9 (outlining the numerous facts that point to premeditation and intent). 
The reaction of the majority of the jurors was also surprising given that McInerney seemed to have been largely provoked by King's words. In most jurisdictions, mere words can never constitute legally adequate provocation. ${ }^{\mathrm{I}} 53$ This is because it is generally thought that people should keep their emotions in check and not react with physical violence when they are verbally insulted. In California, however, verbal provocation can serve to mitigate a murder charge to voluntary manslaughter if the jury chooses to find that the defendant was reasonably provoked by the victim's words and other actions. ${ }^{154}$

It is also noteworthy that a majority of the jurors were inclined to grant McInerney the provocation mitigation despite the fact that the jury was instructed not to let bias against the victim's gender identity influence their deliberations. ${ }^{155}$ This suggests that the anti-bias jury instructions were not effective. One juror felt so strongly that King was the one at fault that she wrote a letter to the district attorney after the trial was over, saying she felt the prosecution of McInerney was a "propaganda filled witch hunt." ${ }^{56}$ That same juror then suggested that King brought on his own death by engaging in "deviant behavior," writing:

You all know this was not a hate crime. You all know the victim had a long history of deviant behavior. Yes, I said deviant. Not his sexual orientation-deviant behavior.... After weeks of testimony, it is my firm belief that this young man [Brandon McInerney] reacted to being bullied and being the target of Larry King's sexual harassment. There was provocation. ${ }^{157}$

\section{Trans Panic}

Claims of trans panic, a defense strategy modeled after the gay panic defense, have garnered increasing attention in recent years. A murder defendant claiming trans panic alleges that he became upset and lost control of his actions upon discovering that he engaged in sexual relations with someone whom he thought was female, but was biologically male. Essential to the claim of trans panic is the argument that the average heterosexual man would have been provoked into a heat of passion if he had discovered that the person with whom he had

I53. Dressler, supra note I4, at § 3I.07(B)(2)(a); Wayne R. LaFAve, Criminal Law 823-35 (5th ed. 20I0).

I54. People v. Berry, 556 P.2d 777, 780 (Cal. I976) (en banc).

I55. Conversation between Cynthia Lee and Maeve Fox, Senior Deputy Dist. Att'y, Ventura Cnty. Dist. Att'y Office (Feb. 6, 20I4) (confirming that anti-bias jury instructions were given in the McInerney case); see Saillant, Trial in Killing of Gay Teen, SUPRA note I29.

I56. Letter from Juror Number i I to Dist. Att'y Gregory D. Totten (Sept. 28, 20 I I) (on file with author). The Author thanks Professor Kelly Strader of the Southwestern Law School in Los Angeles, California, for sharing this letter with her.

I57. Id. 
been sexually intimate was not a "real" female, but a person with male genitalia pretending to be a woman.

The Gwen Araujo case illustrates the trans panic defense strategy in action. On October 3, 2003, I7-year-old Gwen Araujo was brutally beaten to death by a group of four male teenagers she had considered her friends. ${ }^{158}$ Araujo had been sexually intimate with two of the four teens, Jose Merel and Michael Magidson, engaging in oral and anal intercourse with each of them. ${ }^{59}$ The teens began to suspect that Araujo was not biologically female after she refused to have vaginal intercourse with Merel and Magidson on separate occasions, claiming each time to be menstruating. ${ }^{160}$

One night, the teens decided to stop speculating and find out definitely whether Araujo had male or female genitalia. ${ }^{\text {I6I }}$ After Araujo was forced into a bathroom where Nicole Brown, the girlfriend of one of the teens, pulled down Araujo's pants, several of the male teenagers beat Araujo to death. ${ }^{162}$ Three of the teens, Merel, Magidson, and Jason Cazares, were arrested and charged with murder. ${ }^{163}$ The prosecution argued that the defendants should be found guilty of first-degree murder. ${ }^{164}$ Merel and Magidson admitted to having killed Araujo, but asked the jury for a voluntary manslaughter conviction. ${ }^{165}$ Their attorneys argued that the discovery that Araujo was anatomically male was so upsetting that it provoked their clients into a heat of passion. ${ }^{166}$

The jury agreed that Merel and Magidson should be found guilty of murder, but could not come to a consensus on the degree of murder. ${ }^{167}$

I58. People v. Merel, No. A I I3056, 2009 WL I3I4822, at *6-8 (Cal. Ct. App. May I2, 2009). I59. Id. at * $\mathrm{I}$.

I60. Id. (indicating the teens were suspicious because Araujo had told one of the teens she was menstruating just two weeks after she had told the other she was menstruating, and a period usually lasts less than seven days).

I6I. Id. at $*_{2-3}$.

I62. Magidson started by putting his arm around Araujo's throat and choking her repeatedly. Id. at $*_{3}$. Merel followed by using a can of food to hit Araujo on top of her head so hard that the force dented the can. Id. Merel left the room and came back with a frying pan, which he used to hit Araujo on the crown of her head. Id. Next, Magidson punched Araujo twice in the face with a closed fist, and after she dropped to the floor, kneed her twice in the face. Id. at *4. The prosecution argued that Jason Cazares and Jason Nabors encouraged the beating. Id. at * I6.

I63. Id. at *9. "The information included allegations that the defendants had committed a hate crime in concert." Id.

I64. Yomi S. Wronge, Trial Ordered in Teen's Killing; Judge Rules Three Defendants Should Face Charges in October Killing of Transgender Newark Resident, S.F. Chron., Mar. I9, 2003, at BI.

I65. Yomi S. Wronge, Mistrial in Killing of Transgender Teen; Jury Deadlocks on Issue of Premeditation, S.J. Mercury News, June 23, 2004, at Ai.

I66. Id. Cazares claimed he initially stepped in to stop Magidson from harming Araujo and was outside the house when Araujo was being beaten. Merel, 2009 WL I3 14822 , at $*_{5}$ (noting that Cazares testified at trial that he stopped Magidson, Merel, and Nabors several times from beating Araujo and, after realizing Araujo was not a woman, went outside to smoke, returning only after Araujo was dead).

I67. Wronge, supra note i65 (noting that in Merel's case, two jurors voted in favor of first-degree murder while ten jurors voted against, and in Magidson's case, seven jurors voted in favor of first- 
Since the jury was unable to reach a unanimous verdict, the court declared a mistrial. ${ }^{168}$ The State re-filed murder charges against the defendants, again arguing the defendants should be found guilty of firstdegree murder. ${ }^{169}$ After the second trial, a different jury found Merel and Magidson guilty of second-degree murder but did not find them guilty of having committed a hate crime. ${ }^{170}$ Merel and Magidson were sentenced to I5 years to life. ${ }^{17 \mathrm{I}}$

While the teens were ultimately found guilty of murder, the fact that it took two trials led many to feel that the law needed to be changed to prevent defendants from successfully arguing trans panic in the future. In 2006, then-Governor Arnold Schwarzenegger signed A.B. II60, the Gwen Araujo Justice for Victims Act, into law. The Act provides that in any criminal trial or proceeding, upon the request of a party, the court shall instruct the jury as follows:

Do not let bias, sympathy, prejudice, or public opinion influence your decision. Bias includes bias against the victim or victims, witnesses or defendants, based upon his or her disability, gender, nationality, race or ethnicity, religion, gender identity, or sexual orientation. ${ }^{172}$

These anti-bias jury instructions are much like the anti-bias jury instructions in the ABA's August 2013 resolution. ${ }^{173}$

The Gwen Araujo Justice for Victims Act also made legislative findings as follows:

I.It is against public policy for juries to render decisions tainted by bias based upon the victim's actual or perceived disability, gender, nationality, race or ethnicity, religion or sexual orientation, or his or her association with a person or group with one or more of these characteristics.

2. "Panic strategies" are those strategies that try to explain a defendant's actions or emotional reactions based upon the knowledge or discovery of the fact that the victim possesses one or more of the characteristics listed above or associates with a person or group with one or more of these characteristics.

\footnotetext{
degree murder while five voted against). The jury also deadlocked on Cazares. Ivan Delventhal, Deliberations Hung Up on Degree of Charges, Inside Bay Area News (June 23, 2004, 7:55 AM), http://www.insidebayarea.com/news/ci_235724I (noting that the jury was Io to 2 in favor of acquitting both Merel and Cazares of first-degree murder and 7 to 5 in favor of convicting Magidson of firstdegree murder).

I68. Merel, 2009 WL I3 34822 , at *9.

I69. Yomi S. Wronge, Opening Arguments in Murder Case Retrial, S.J. Mercury News, Jun. 2, 2005, at BI.

I70. Merel, 2009 WL I3I4822, at *9; Wronge, SUPRA note I5I. The second jury, like the first, could not reach a verdict on Cazares, so a mistrial was again declared as to Cazares. Merel, 2009 WL I3I 4822 , at *9.

I7I. Wronge, supra note I5I.

172. Gwen Araujo Justice for Victims Act, Cal. Penal Code § i 27 h (West 20I4).

I73. Am. Bar Ass'n., supra note 1.
} 
3.The Legislature is concerned about the use of societal bias in criminal proceedings and the susceptibility of juries to such bias. The use of so-called "panic strategies" by defendants in criminal trials opens the door for bias against victims based on one or more of the characteristics listed above or an association with a person or group with one or more of those characteristics.

4.It is against public policy for a defendant to be acquitted of a charged offense based upon an appeal to the societal bias that may be possessed by members of a jury. ${ }^{174}$

A separate provision of the bill that would have precluded defendants from making gay or trans panic arguments did not pass. ${ }^{\mathrm{I}}{ }^{7}$ Concerns about the constitutionality of such a provision taking away the ability of a defendant to present a defense may have prompted the rejection of this part of the bill. ${ }^{176}$

A similar bill recently made its way through the California legislature. ${ }^{\mathrm{I77}}$ In February 20I4, Assemblywoman Susan Bonilla introduced A.B. 250I, which California Governor Jerry Brown signed into law in September 2014. ${ }^{178}$ The law, which amends Section I92 of the California Penal Code, bars defendants in California from contending that they were provoked into a heat of passion by the discovery of the victim's sexual orientation or gender identity. ${ }^{179}$

\section{Behind the Claims of Trans Panic}

When a heterosexual man kills a transgender woman, his claim of trans panic may evoke feelings of sympathy or empathy, especially in male jurors who themselves may be extremely uncomfortable with the thought of unwanted male sexual contact and may view the transgender female as a man despite her outward appearance and self-identification

I74. Penal § i I $27 \mathrm{~h}$.

175. See Wronge, supra note II7 (noting that the first version of A.B. I I6o sought to block defendants charged with a hate crime from asserting a heat of passion defense, but was defeated amid opposition from Campaign for California Families, a conservative lobbying group).

I76. But see Memorandum re: Constitutional Analysis of A.B. I I60: Validity of Due Process Challenges to Legislation Eliminating Gay and Trans Panic Defenses in California from R. Bradley, Williams Project, UCLA School of Law, to Senator Sheila Kuehl (Feb. 2, 2005), AVAILABLE AT http://williamsinstitute.law.ucla.edu/wp-content/uploads/Sears-Kukura-CA-AB I I6o-Memo-Feb2005.pdf (concluding that a statute defining legally adequate provocation for a heat of passion defense to exclude gay and trans panic defenses would not violate a defendant's due process rights).

I77. Assemb. B. 250I, 20I3-I4 Leg., Reg. Sess. (Cal. 20I4); California: Bill To Curb "Gay Panic" Defense Advances, SDGLN.com (Apr. 30, 20I4), http://www.sdgln.com/news/2014/04/30/californiabill-curbing-gay-panic-defense-advances\#sthash.tHrUuOPW.dpbs (noting that A.B. 250I passed the Assembly Public Safety Committee with a vote of $5^{-\mathrm{I}}$ and moves next to the Assembly Appropriations Committee). The full text of this legislation can be found at http://legiscan.com/CA/text/AB250r/id/Ior4787.

I78. Seth Hemmelgarn, Proposal to Ban 'Gay,' 'Trans' Panic Defenses Introduced, EBAR.com (Feb. 26, 20I4, 5:43 PM), http://ebar.com/blogs/proposal-to-ban-gay-trans-panic-defenses-introduced.

I79. 2014 Cal. Legis. Serv. ch. 684 (A.B. 250I) (West) 
as a female. Whether the jury finds that the defendant was reasonably provoked may turn on the defendant's underlying motivation for violence. In this Part, we examine three possible motivations for the defendant's violence: (I) the defendant's fear of being seen as gay if others find out he had sex with a transgender individual, (2) the defendant's desire to enforce gender norms, and (3) the defendant's anger at the victim's alleged deceit. We also address the normative question of whether any of these motivations ought to support the claim that the defendant was reasonably provoked.

\section{A. Protection of the Masculine Identity and the Fear of Being SEen as Gay}

First and foremost, the defendant's violence may be motivated by his fear of being seen as gay. The male defendant who kills a transgender woman with whom he has been sexually intimate may believe that his attraction to someone who is biologically male reflects his own latent homosexuality. He may be afraid that if others find out that he was sexually intimate with a transgender woman, they will think he is gay. ${ }^{180}$ The heterosexual man who believes in traditional gender roles may also see the fact of his having had sex with a transgender female as a threat to his masculine identity that has to be quashed.

Scholars in the field of masculinities theories observe that in the United States, men are socialized to believe that being a man means not being a woman and not being gay. ${ }^{18 \mathrm{I}}$ As Michael Kimmel explains, "being a man means "not being like women," which requires that one not desire other men or at least ensure that "no one could possibly ever

\footnotetext{
I80. If the man who kills a male-to-female transgender person believes that the victim's true sex is male, he may believe that any sex he had with the victim was homosexual sex. The trans female who dates straight men, however, does not view herself as homosexual. If she prefers to date men, her sexual orientation is decidedly heterosexual.

I8I. Ann C. McGinley, Work, Caregiving, and Masculinities, 34 Seattle U. L. Rev. 703, 707 (20II) ("For many men, defining oneself as 'masculine,' requires proof of two negatives: that one is not feminine or a girl, and that one is not gay."); Ann C. McGinley, Reproducing Gender on Law School Faculties, 2009 BYU L. Rev. 99, I08 ("Masculinity involves a flight from the feminine and a fear of homosexuality."); Ann C. McGinley, Ricci v. DeStefano: A Masculinities Theory Analysis, 33 Harv. J.L. \& Gender 58I, 586 (2010) (noting that White middle class college men who are members of fraternities gain acceptance by proving their masculinity to each other, which often involves mistreating gay men and participating in gang rapes of women); Ann C. McGinley, Harassing 'Girls' at the Hard Rock: Masculinities in Sexualized Environments, 2007 U. ILL. L. Rev. I229, I25I ("Difference from girls is an integral component in the construction of dominant masculinity.") (citing Jon Swain, Masculinities in Education, in Handbook of Studies on Men \& Masculinities 213, 223 (Michael S. Kimmel et al. eds. 2005)); Ann C. McGinley, Masculinities at Work, 83 Or. L. Rev. 359, 408 (2004) (noting that under hegemonic masculinity, gay men are seen as feminine) (citing RoBerT W. ConNell, Masculinities 78 (I995)).
} 
mistake one for a homosexual." ${ }^{82}$ Similarly, Frank Rudy Cooper observes that a central feature of masculinity is the need to denigrate and repudiate those who are not considered masculine, namely women, gays, and racial minorities. ${ }^{183}$

Masculinities scholars speak of "masculinities" in the plural because there are different ways of establishing masculinity. ${ }^{184}$ As Angela Harris notes, hegemonic masculinity, the kind of masculinity to which white heterosexual middle and upper class men aspire, is marked by financial and political power over other men and women, intellectual mastery, and technological prowess. ${ }^{185}$ For these men, being a man means being in power. ${ }^{186}$ In contrast, men of color and working class men, who often are unable to attain hegemonic masculinity either because they lack the education and training to exhibit technological prowess or because they take orders rather than give them, construct "rebellious forms of manhood." ${ }^{8} 77$ Harris notes that working class men and men of color often "resort to 'hypermasculinity' (the exaggerated exhibition of physical strength and personal aggression) in an attempt to gain social status."I88 Masculinity, for these men, is reflected in physical strength and sexual prowess. ${ }^{189}$ They may use violence to prove their masculinity, particularly when they feel their masculine identity is being threatened. ${ }^{190}$

When a heterosexual man is sexually intimate with a transgender woman, the heterosexual man may worry that those who find out he was sexually intimate with a person who is biologically male will think he is gay. In these situations, killing the transgender woman reinforces and affirms the defendant's masculine identity in two ways. First, the defendant shows the world that he is disgusted with the thought of having sex with another man, and, therefore, he is not gay. Second, the defendant attempts to demonstrate that he is not a woman by acting aggressively and with brute physical force.

Take, for example, the killing of Gwen Araujo, discussed above. Testimony at trial revealed that Merel became very upset when he

i82. Michael S. Kimmel, Masculinity as Homophobia: Fear, Shame, and Silence in the Construction of Gender Identity, in The Gender of Desire: Essays on Male Sexuality 25, 3I-34 (2005).

I83. Frank Rudy Cooper, Our First Unisex President?: Black Masculinity and Obama's Feminine Side, 86 Denv. U. L. Rev. 633, 648 (2009); see Frank Rudy Cooper, Hyper-incarceration as a Multidimensional Attack: Replying to Angela Harris Through The Wire, 37 WASH. U. J.L. \& PoL'y 67, 75 (20I I) (noting that the attempt to prove one's masculinity leads to attempts to distinguish oneself from other, less masculine figures, such as women, racial minorities, Jews, and gay men).

I84. Harris, supra note II, at 783.

I85. Id. at 783,784

I86. $I d$.

I87. Id. at $784-85$.

I88. Id. at 785 .

I89. Id.

190. Id. at $78 \mathrm{I}$. 
started thinking that Araujo might have been born with male genitalia. Merel thought this meant that he himself was gay since he had found Araujo to be sexually attractive and had enjoyed oral and anal intercourse with Araujo. ${ }^{19 \mathrm{I}} \mathrm{He}$ was so distraught when he found out that Araujo had male genitalia that his initial reaction was to vomit, and then cry-not very "manly" ways to react. ${ }^{192}$ While his brother Emmanuel (Manny) and friend Nicole Brown tried to console him, Merel kept saying he could not believe he was gay. ${ }^{193}$

According to Bill DuBois, Merel's attorney, Merel was very fond of Araujo and had a romantic attachment to her. ${ }^{194}$ When Merel discovered Araujo was not biologically female, he experienced a crisis of selfconception. ${ }^{195}$ In other words, finding out that he had been attracted to a person with a penis made him doubt his own masculinity and heterosexuality. Michael Thorman, Magidson's attorney, asserted a similar argument. According to Thorman, Magidson was shocked when he discovered Araujo had male genitalia. ${ }^{196}$ Thorman characterized Araujo's actions as "theft of heterosexuality," arguing to the jury that Araujo had stolen Magidson's masculine identity. ${ }^{197}$

The trans panic defense rests, in part, on the idea that the victim robbed the defendant of his masculinity by tricking him into having sex with a man pretending to be a woman. The defendant arguing trans panic suggests that his fear of being seen as gay is a reasonable fear, one that most men would have if they found themselves in a similar situation. The defendant arguing trans panic suggests that his fear of being seen as gay is a reasonable fear, one that most men would have if they found themselves in a similar situation, and therefore, the jury should find that he was reasonably provoked into a heat of passion by the victim's deception about her biological sex. A fear of being gay, however, should not be grounds to mitigate a murder charge to manslaughter. Just as fear of being seen as a coward has never constituted legally adequate provocation, neither should fear of being seen as gay.

i9i. People v. Merel, No. Ai I3056, 2009 WL I3 I4822, at*7 (Cal. Ct. App. May i2, 2009).

I92. When Magidson first came outside the bathroom and told Merel, "That's a man. I know that's a man," Merel vomited. Id. When Nicole Brown came out of the bathroom and confirmed that she had seen male genitalia on Araujo, Merel began to cry. Id.

I93. Id.

I94. William H. DuBois, Criminal Defense Atty., Remarks at UC Hastings College of the Law Symposium on Hate Crimes: Combating Gay \& Transgender "Panic" Strategies (July 20-2I, 2006), available at www.ebar.com/news/article.php?sec=news\&article=1028.

I95. Id.

I96. Michael P. Thorman, Criminal Defense Atty., Remarks at UC Hastings College of the Law Symposium on Hate Crimes: Combating Gay \& Transgender "Panic" Strategies (July 20-2 I, 2006), available at www.ebar.com/news/article.php?sec=news\&article= 028 .

I97. Id. 


\section{B. Sexual Prejudice and the Enforcement of Gender Norms}

Second, the defendant's violence may be motivated by his extreme discomfort with any manifestation of gender non-conformity. His act of killing the transgender woman reflects a desire to enforce prevailing gender norms that align sex with gender and masculine identity with heterosexual orientation. As Aaron Norton and Gregory Herek note, "transgender identities pose a challenge to the widespread assumptions that [male] gender and biological sex are binary categories . . . " 198 Most people assume that a person born with male genitalia is a man and a person born with female genitalia is a woman. ${ }^{199}$

Negative attitudes toward sexual and gender minorities appear to be closely bound to heteronormative ${ }^{200}$ attitudes about gender identity, patriarchal authoritarianism, and masculinity. ${ }^{201}$ Transgender people disrupt the "stability of both gender and sexual orientation categories." ${ }^{202}$ Even though the transgender woman who enjoys sex with men is actually heterosexual, the defendant views her as a homosexual man, because she is biologically male and enjoys sex with men.

Norton and Herek observe a link between heterosexual prejudice against gays, lesbians, and bisexuals and prejudice against transgender people:

$[\mathrm{H}]$ eterosexuals' attitudes towards transgender people displayed many of the patterns consistently observed in their attitudes towards gay men, lesbians, and bisexuals. They were significantly correlated with higher levels of psychological authoritarianism, political conservatism and anti-egalitarianism, and (for women) religiosity - variables that are also consistent predictors of sexual prejudice. These patterns suggest that negative attitudes toward transgender people may have their psychological roots in strong support for existing social conventions, power hierarchies, and traditional values. In this respect, they are similar not only to sexual prejudice but also to negative attitudes toward outgroups in general. ${ }^{203}$

I98. Aaron T. Norton \& Gregory M. Herek, Heterosexuals' Attitudes Toward Transgender People: Findings from a National Probability Sample of U.S. Adults, 68 Sex Roles 738, 740 (20I2).

I99. See Valdes, supra note 28, at 20.

200. For definition of "heteronormativity," see supra note I2 and accompanying text.

20I. Norton \& Herek, supra note 198, at 746-48; see Eric Anderson, "Being Masculine Is Not About Who You Sleep with...": Heterosexual Athletes Contesting Masculinity and the One-time Rule of Homosexuality, 58 Sex Roles I04, I05 (2008) ("[T]he stigma associated with men's homosexuality reflects more than just the dislike of sex between men: male homosexuality is also disparaged because it is culturally conflated with femininity ....").

202. Norton \& Herek, supra note I98, at 74I (Transgender people "violate...the "natural attitude' toward gender by changing from one gender to another or by not confirming to societal expectations for male- or female-bodied people."); see Shinsuke Eguchi, Negotiating Hegemonic Masculinity: The Rhetorical Strategy of "Straight-Acting" Among Gay Men, 38 J. Intercultural Сомм. Res. I93, 207 (2009).

203. Norton \& Herek, supra note I98, at 749 (citation omitted). Elsewhere, Herek has noted that sexual prejudice "is almost always directed at people who engage in homosexual behavior or label 
Importantly, Norton and Herek found that "attitudes toward transgender people were significantly more negative than attitudes toward sexual minorities." 204

For defendants asserting the trans panic defense, the transgender woman transgresses gender norms by assuming a female identity when she was born with male anatomy. The defendant punishes her act of transgression by killing her. The law, however, generally disapproves of acts of violence, like bullying, that are motivated by a desire to enforce gender norms. ${ }^{205}$ Likewise, the law of provocation should not countenance the use of violence to enforce gender norms.

\section{Blaming the Victim for Her Alleged Deceit}

The defendant's violence may also be motivated by his belief that the transgender victim was deceitful and misrepresented her true gender identity. ${ }^{206}$ The defendant in a trans panic case thinks the victim deceived

themselves gay, lesbian or bisexual." Gregory M. Herek, The Psychology of Sexual Prejudice, 9 Current Directions in Psychol. Sci. I9, I9 (2000).

204. Norton \& Herek, supra note I98, at 749 (emphasis added).

205. Safe Place to Learn Act, Cal. Educ. Code $\S 234$ (West 20I4); Wash. Rev. Code AnN. $\S 28$ A.300.285 (West 20I4); Lisa C. Connolly, Anti-gay Bullying in Schools-Are Anti-Bullying Statutes the Solution?, 87 N.Y.U. L. Rev. 248 (2012) (noting that anti-bullying legislation has proliferated in the last decade); see R. Kent Piacenti, Toward a Meaningful Response to the Problem of Anti-gay Bullying in American Public Schools, I9 VA. J. Soc. PoL'Y \& L. 58 (20I I) (arguing that state anti-bullying statutes are inadequate and suggesting LGBT protections should be added to Title IX). Most of the existing anti-bullying legislation is found in state civil codes. In May 20I4, the city of Carson, California, a suburb of Los Angeles, became the first in the nation to consider enacting an anti-bullying statute that would make repeated bullying a crime. See David Ingram, California City Close to Finalizing Tough Anti-bullying Ordinance, MSNBC (May 15, 2014, 2:2 I PM), http://www.msnbc.com/craig-melvin/california-citys-anti-bullying-ordinance (noting that the proposed ordinance "targets kindergarteners through adults age 25 who make another person feel "terrorized, frightened, intimidated, threatened, harassed, or molested' with no legitimate purpose" and that "firsttime offenders will be fined $\$ 100$," second time offenders will be fined $\$ 200$, and "a third offense could bring a criminal misdemeanor charge"); Bullying Battle: California City Could Become Nation's First Zero-tolerance Zone for Bullies, CBS News (May 20, 2014, 2:49 PM), http://www.cbsnews.com/news/carson-california-could-pass-anti-bullying-ordinance-and-becomenations-first-no-tolerance-zones (noting that "[i]f passed, the city could become one of the nation's first no-tolerance zones for bullies"). In the end, the anti-bullying ordinance did not pass. Tracy Bloom, Anti-bullying Ordinance Defeated by Carson City Council Vote, KTLA.com (May 20, 2014, Io:03 PM), http://ktla.com/20I4/05/20/anti-bullying-ordinance-in-carson-set-for-vote.

206. In Queer (In)Justice, Joey Mogul, Andrea Ritchie, and Kay Whitlock discuss ways in which the archetypal narrative of transgender people as inherently deceptive is reflected in criminal statutes that prohibit cross-dressing and comments by judges and prosecutors in criminal cases. MogUL ET AL., supra note 8 , at 73, 76. For example, at one time an Ohio criminal statute "made it illegal for any 'perverted person' to appear in clothing belonging to 'the opposite' sex.'” Id. at 73 (citing I. Bennett Capers, Cross Dressing and the Criminal, 20 Yale J.L. \& Human. I (2008)). In another case, a judge in New Jersey refused to allow a transgender woman to change her name on the ground that "it is inherently fraudulent for a person who is physically a male to assume an obviously 'female' name for the sole purpose of representing herself to future employers and society as a female." Id. at 73 (citing In re Eck, 584 A.2d 859, 860 (N.J. Super. Ct. App. Div. 199I)). In another case involving a Black transgender woman charged in 2007 with attempted murder, the prosecutor told the jury, "How can 
him by pretending to be a woman when "he" ${ }^{207}$ was actually a man. The defendant alleges that his discovery of the victim's "true" 208 gender identity - finding out the victim was a "he" rather than a "she"- upset him so much that he lost self-control. The defendant also argues that the average heterosexual man in his shoes would have been equally upset, and therefore he was reasonably provoked into a heat of passion.

In many cases, it will be quite apparent that a transgender person is transitioning. ${ }^{209}$ In such cases, a defendant's claim that the victim was deceptive about her true sex should be viewed with skepticism. Moreover, one might question whether a transgender woman who does not disclose her biological sex is being deceitful. Does one have a duty to reveal everything about oneself to a person with whom one is sexually intimate? When does such a duty arise? An individual with an ugly birth defect in a private place might not disclose this to a potential sexual partner, hoping that the relationship develops to a more serious level before revealing such information. ${ }^{210}$

In examining the defendant's claim that the transgender victim's misrepresentation about her "true" gender identity was what caused the defendant to lose self-control, and whether the alleged deception ought to be cognizable as legally adequate provocation, one might draw an analogy to rape law's distinction between fraud-in-the-factum and fraudin-the-inducement. ${ }^{2 I}$ As Russell and Kathryn Christopher explain, "[f]raud, along with force and coercion, is one of the three principal

you trust this person? He tells you he is a woman; he is clearly a man." Id. at 76 . In yet another example in 1994, Sean O'Neil, a White transgender man, was charged with criminal impersonation and sexual assault after having consensual sex with four underage teenage girls. Id. at 77 . The teenage girls admitted that the sex with O'Neil was consensual but the prosecutor argued that because O'Neil was a transgender man, their consent was procured by fraud, involuntary, and therefore invalid. Id. In light of the fact that he faced a twenty year prison sentence if convicted, O'Neil pled guilty to seconddegree sexual assault. $I d$. at 78 . He was sentenced to three months in a women's prison and required to register as a sex offender. Id. Apparently influenced by the idea that a transgender person is being deceptive when he or she fails to disclose their biological sex, the judge opined at O'Neil's sentencing hearing, "What this case is about is deceit." Id. at 77.

207. We use quotation marks around the word "he" to emphasize that it is the defendant who views the transgender woman as a man The defendant uses the male pronoun to refer to the victim even though the female pronoun is more appropriate.

208. We put the word "true" in quotation marks because we contest the view that a transgender woman is misrepresenting her gender identity when she presents herself to the world as female.

209. Prior to gender reassignment surgery, a transgender woman may wear makeup, dresses, and heels, but an Adam's apple or large hands and feet may make it obvious to others that she is transitioning. Similarly, a transgender man may wear attire usually associated with men, such as a tuxedo or suit and tie, but feminine facial and body features may make it apparent to others that he is transitioning.

2 I0. We thank Professor Courtney Joslin at UC Davis School of Law for suggesting this line of inquiry.

2I I. In doing so, we do not mean to suggest that the transgender woman who does not disclose her biological sex to an intimate partner is engaging in fraudulent behavior. 
means by which a person can commit rape." 212 "Obtaining intercourse through fraud, just as through force and coercion, constitutes rape because it vitiates the consent of the victim."213

Rape law, however, distinguishes between actionable and nonactionable rape-by-fraud by examining the type of fraud that encouraged the victim to say "yes." As Jed Rubenfeld notes, as a general matter, sexby-deception is not recognized as rape. ${ }^{214}$ Sex-by-deception constitutes rape only when the victim is deceived as to the nature of the act. For example, if the victim thinks she is being subjected to a medical procedure when the defendant is actually inserting his penis into her vagina, the defendant's act will be construed as non-forcible rape. ${ }^{215}$ Such cases involve fraud-in-the-factum, which invalidates the victim's consent, and makes the defendant's conduct actionable as rape-by-fraud. ${ }^{216}$ If the victim knows that she is engaging in the act of sexual intercourse but is deceived as to some collateral matter (for example, she thinks the defendant is a famous rock star when he is not), this constitutes fraud-inthe-inducement, and is not grounds for a claim of rape-by-fraud. ${ }^{217}$

2I2. Russell L. Christopher \& Kathryn H. Christopher, Adult Impersonation: Rape by Fraud as a Defense to Statutory Rape, I0I Nw. U. L. Rev. 75, 77 (2007).

213. Id.

2I4. Jed Rubenfeld, The Riddle of Rape-by-Deception and the Myth of Sexual Autonomy, I22 YALE L.J. 1372, I395-96 (2013) (defending the force requirement in rape law and the general rule that sex-by-deception does not constitute rape). Rubenfeld notes that Anglo-American courts recognize only two exceptions to this general rule: sex falsely represented as a medical procedure and impersonation of a woman's husband. Id. at I397; see Anne M. Coughlin, Sex and Guilt, 84 VA. L. REv. I, I9 (I998) (noting that "[t]he traditional approach holds that it is a crime to obtain sexual intercourse by fraud in only two narrow contexts," namely (I) when a man deceives a woman into thinking she is submitting to a nonsexual act, and (2) when a man obtains intercourse by masquerading as the woman's husband).

215. See, e.g., People v. Minkowski, 23 Cal. Rptr. 92, 94-96 (Cal. Ct. App. I962) (defendant was a physician who "treated" patients for menstrual cramps by having them bend over a table while the doctor first inserted a metal instrument into their vagina from behind, then substituted a different "instrument" that was in fact the doctor's penis).

216. Christopher \& Christopher, supra note 2I2, at 83 ("Fraud in the factum consists of a deception or fraud as to the fact, or act, or nature of the act, itself."); Patricia J. Falk, Rape by Fraud and Rape by Coercion, 64 Ввоок. L. Rev. 39, 5I (1998) (referring to fraud-in-the-factum as "mistake as to the act itself"); see Martha Chamallas, Consent, Equality, and the Legal Control of Sexual Conduct, 6I S. CALIF. L. Rev. 777, 83I n.224 (I988) ("Fraud in the factum typically denotes a situation in which the victim consents to the doing of act $X$ and the perpetrator of the fraud, in the guise of doing act $\mathrm{X}$, actually does act Y.").

217. Christopher \& Christopher, supra note 212, at 83 ("Fraud in the inducement consists of deception or fraud neither to the fact, nor act, nor nature of the act, nor 'to the thing done, but [rather] ... to some collateral matter'."); Falk, supra note 2I6, at 5I (referring to fraud-in-theinducement as "mistake about the reason for doing the act"). See, e.g., Boro v. Superior Court, 2 Io Cal. Rptr. I22, I23-24 (Cal. Ct. App. 1985) (finding fraud-in-the-inducement where the defendant, pretending to be a doctor, told a woman that she had contracted a highly infectious and possibly fatal disease and the only way to treat the disease was to have sexual intercourse with an anonymous donor who had been injected with a serum or undergo an expensive and painful surgical procedure). The law on rape-by-deception is changing. As Jed Rubenfeld notes, "[i]n Tennessee, rape is already defined to 
If a trans panic case involves fraud-in-the-factum, then the defendant may be able to convince the jury that he was raped-his consent to the act of sexual intercourse with the transgender victim was invalid due to fraud-in-the-factum, and therefore his outrage at the discovery that his sexual partner was biologically male was reasonable. The defendant would argue that the transgender woman tricked him into engaging in a sex act when he was not fully aware of what he was doing.

In perhaps the only published law review article to date that defends the use of the trans panic defense strategy, Bradford Bigler argues that sexual misrepresentation cases involving a transgender woman's failure to disclose her biological sex ought to count as legally adequate provocation under certain circumstances. ${ }^{218}$ Rather than viewing cases where a transgender female is intimate with a heterosexual man without revealing her biological sex as fraud-in-the-inducement, Bigler thinks that trans panic cases straddle the line between fraud-in-inducement and fraud-in-the-factum. He acknowledges that trans panic cases look like fraud-in-the-inducement because "both parties are fully aware of the sexual nature of the act." 19 Bigler argues, however, that because the defendant is deceived as to the biological sex of his partner, "the nature of the sex to which the deceived party consents (for example, heterosexual sodomy in the case of Araujo) is fundamentally different [from] the act in which the defendant actually engaged (here, homosexual sodomy)." 220

The problem with Bigler's argument is that the defendant who engages in sodomy with a transgender female is not engaging in homosexual sodomy. The transgender female who dates straight men is heterosexual. She is a woman who prefers to be intimate with men, not women. When she allows a man to have anal intercourse with her, this act of anal intercourse is an act of heterosexual sodomy, not homosexual sodomy. ${ }^{22}$ It only looks like homosexual sodomy if we adopt the defendant's view of the world and equate gender with sex. As discussed earlier, the binary view of sex and gender is problematic because it fails

include 'sexual penetration ... accomplished by fraud," and "[a] man commits rape in Idaho, under a 201 I amendment, when he has sex with a woman who, because of his 'artifice, pretense, or concealment,' believes him to be 'someone other than' who he is." Rubenfeld, supra note 2 I4, at I 375 .

218. Bigler, supra note Io, at 786 (arguing that a transgender woman's failure to disclose her biological sex ought to count as legally adequate provocation where: (I) the defendant engaged in a sexual act while reasonably deceived as to his partner's biological sex, (2) the defendant would not have engaged in that sexual act had he known of his partner's biological sex, and (3) a reasonable person in his shoes would have suffered a severe mental or emotional crisis upon discovery of the truth).

2 I9. Id. at 800 .

220. Id. at 800-0I

22 I. Vade explains that "gender identity" is "who one is", whereas "sexual orientation" is "to whom one is attracted." Vade, supra note 24, at 270. Vade notes that "[t]ransgender people have all sexual orientations: some transgender people are straight, some are gay, some are bisexual, and some are queer." Id. 
to account for individuals whose biological sex differs from their gender identity and conflates gender identity and sexual orientation. ${ }^{222}$

The argument that the defendant is deceived as to the nature of the act fails for another reason. In most trans panic cases, the defendant knows full well that he is engaging in oral or anal intercourse. If the defendant is deceived about anything (in many cases, there is reason to doubt that the defendant was actually deceived about the victim's transgender status), he is deceived regarding his partner's biological sex. Whether you call his act of oral or anal intercourse homosexual sodomy or heterosexual sodomy, sodomy is sodomy (whether oral or anal). As such, the defendant knew that he was engaging in sodomy at the time. ${ }^{223}$

Bigler further contends that the sexual identity cases are similar to cases involving a woman who has sex with a man she thinks is her husband, but who is actually an imposter. ${ }^{22}$ Courts are split over whether the marital fraud cases (also known as "husband impersonation") constitute fraud-in-the-factum or fraud-in-theinducement. ${ }^{225}$ Under one view, the marital fraud cases are understood as cases involving fraud-in-the-factum ${ }^{226}$ on the ground that the wife thought she was engaging in marital sex when she was actually engaging in adulterous sex. ${ }^{227}$ Because the wife was deceived as to the true nature

222. See supra notes $27-35$ and accompanying text.

223. The defendant may assert that he thought he was engaging in vaginal intercourse, rather than anal intercourse. In such a case, the prosecutor might counter that the defendant knew he was engaging in sexual intercourse (whether vaginal or anal), and therefore there was no fraud-in-the-factum.

224. Bigler, supra note io, at 800.

225. Id. See, e.g., People v. Evans, 379 N.Y.S.2d 912, 919 (N.Y. Sup. Ct. 1975) (opining in dicta that it is not rape when a woman has intercourse with a man impersonating her husband). But see Boro v. Superior Court, 2 Io Cal. Rptr. I22, I24-25 (Cal. Ct. App. I985) (noting in dicta that spousal impersonation is fraud-in-the-factum and therefore rape); see also Rubenfeld, supra note 2I4, at I39798 ("[T]he spousal-impersonation exception is the law of at least fourteen states, including California, and is recognized in the Model Penal Code.").

226. State v. Navarro, 367 P.2d 227, 228 (Ariz. I96I) (defendant convicted of rape after crawling into victim's bed and impersonating her husband under Arizona statute defining rape to include inducement through impersonation of the victim's husband); Pinson v. State, 5I 8 So. 2 d I220 (Miss. I988). In a recent case, a California Court of Appeal overturned the lower court's conviction of a man who had impersonated the victim's boyfriend in order to have sexual intercourse with her, finding that "[a] man who impersonates someone in order to have sexual intercourse may be guilty of rape only if the victim was married and the man was pretending to be her husband." Maura Dolan, Voiding of Rape Conviction Involving Sleeping Woman Called "Bizarre," L.A. Times Blog (Jan. 4, 20I3, 7:33 AM), http://latimesblogs.latimes.com/lanow/20I3/or/rape-case-voiding-involving-sleeping-womancalled-bizarre-.html.

227. Falk, supra note $2 \mathrm{I} 6$, at 66-67 ("[H] usband impersonation cases really involve fraud in the factum because the woman has consented to marital intercourse not adultery and, therefore, the impersonator's fraud vitiates her consent.") (citing Regina v. Dee, I5 Cox CC 579 (Ir. I884)). For an excellent discussion of the way both family law and criminal law reinforce a binary view of sexual intercourse as either marital, and thus legal, or non-marital, and thus illegal or illegitimate, see generally Melissa Murray, Strange Bedfellows: Criminal Law, Family Law, and the Legal Construction of Intimate Life, 94 IowA L. REv. I253 (2009). Under the historical binary view of sex, the wife who has sex with the husband impersonator agrees to engage in lawful marital intercourse, not unlawful 
of the sex act, supporters of this view say her consent must be invalidated as induced by a fraud-in-the-factum. ${ }^{228}$ Drawing a distinction between marital sex and adulterous sex, however, obscures the bottom line. Whether labeled marital sex or adulterous sex, the act in question still constitutes sexual intercourse.

We think the marital fraud cases are better understood as cases involving fraud-in-the-inducement. In the marital fraud cases, the wife understands that she is engaging in sexual intercourse and is merely deceived regarding the identity of the person with whom she is engaging in sexual intercourse. The marital fraud cases are thus akin to cases in which a man induces a woman to have sex with him by pretending to be someone he is not, such as a wealthy businessman, a Playboy photographer, or a man who intends to marry her. ${ }^{22}$ Such cases, without a doubt, involve fraud-in-the-inducement. The fact that the women in these cases would not have consented to the sexual intercourse had they known the truth about the man's identity does not invalidate their consent.

This is not to say that we approve of men who masquerade as a woman's husband in order to get her to engage in sexual intercourse. We would have no objection if a legislature made spousal impersonation in order to achieve sexual intimacy a crime separate and apart from the crime of rape, punishable by sentences just as severe as other types of non-forcible rape. We simply think it is a stretch to try to squeeze husband impersonation cases into the fraud-in-the-factum category when they more closely resemble the fraud-in-the-inducement cases.

We also think that claims of sexual deception made by a defendant asserting a trans panic defense are better understood as cases of fraud-inthe-inducement, if fraud at all, ${ }^{230}$ not fraud-in-the-factum. ${ }^{23^{\mathrm{I}}}$ Just like the

\footnotetext{
adultery or sex outside the marriage, providing support for the view that the marital fraud cases constitute examples of fraud-in-the-factum.

228. Falk, supra note 216, at 66-67.

229. Christopher \& Christopher, supra note 2I2, at 89 ("[F]raud as to one's societal status, wealth, or physical appeal is generally not treated as rape.").

230. Again, we question whether a transgender woman has an obligation to disclose her transgender identity or sex assigned at birth to a sexual partner. See supra text accompanying note 2 Io. Should a woman who was born with an enlarged clitoris be under an obligation to disclose to a sexual partner, prior to engaging in sexual relations, that she had her clitoris surgically altered? If she were to fail to disclose this fact, would we think she had engaged in fraudulent behavior? Most likely we would not. Should a bisexual woman be under any obligation to tell a man with whom she plans to be intimate that she has previously engaged in sexual activity with other women? If she fails to disclose this information, is she being deceptive? Has she engaged in fraudulent behavior? We think not. If a transgender woman has undergone sex reassignment surgery and has officially changed her sex and gender identity on her birth certificate and driver's license, is it correct to say that she is being deceitful if she fails to disclose to a sexual partner that she was born with male genitalia? Arguably, she is simply representing herself as her legal sex. We thank Courtney Joslin for suggesting this series of questions.
} 
woman who is induced into having sex with a man who falsely professes his love for her but knows that she is engaging in sexual intercourse with that man, the man who has sex with a transgender woman knows exactly what he is doing when he engages in oral or anal intercourse with her. In both cases, there is valid consent to the act of sex. Since misrepresentations for the purpose of getting someone to engage in sexual intercourse, including false representations as to one's marital status, profession, or class, and false pronouncements of love or marriage, are generally seen as fraud-in-the-inducement and not sufficient to invalidate consent to the sexual intercourse, any alleged misrepresentation by the victim regarding her biological sex is more akin to fraud-in-the-inducement than fraud-in-the-factum. Therefore, the law should not consider such acts as legally adequate provocation sufficient to mitigate the charge of murder to manslaughter. ${ }^{232}$

In the end, looking to rape law's distinction between fraud-in-thefactum and fraud-in-the-inducement may not be all that helpful in terms of deciding whether a man who kills upon the discovery that his sex partner is biologically male has been reasonably provoked. ${ }^{233}$ A person who agrees to have sex with another based on a fraud-in-the-inducement may be just as outraged when she discovers the truth as a person who agrees to have sex with another based on a fraud-in-the-factum. ${ }^{234}$ Whether that outrage is normatively appropriate when it results in fatal violence is another question. We think it is not normatively appropriate to be outraged by the discovery that one's intimate partner is a transgender person.

\section{Legislative Bans and Other Proposals for Reform}

It is clear that the trans panic defense strategy is problematic because it reifies structures of masculinity and reinforces negatives stereotypes about transgender individuals as sexual deviants. It is also

23I. Tilleman, supra note I0, at I68I (arguing that the trans panic cases "bear more resemblance to the theoretical concept of fraud in the inducement than they do to fraud in the factum").

232. Id. at 1682 .

233. Ultimately, even Bigler acknowledges that "rape doctrine offers a poor analytical framework" for understanding whether trans panic cases ought to be viewed as cases involving legally adequate provocation because "[t]he provocation defense is most interested in whether a defendant was reasonably in a heat of passion, but the fraud in fact/fraud in the inducement distinction does not distinguish usefully between those cases in which a heat of passion would be reasonable, and those in which it is not." Bigler, supra note io, at $80 \mathrm{I}$.

234. As Bigler points out, a woman who is duped into having sex with a man who tells her it is the only way to immunize herself against a fatal disease without paying for extensive and painful medical treatment probably feels just as angered as a woman who is duped by a doctor who tells her he is inserting a medical instrument into her vagina, when he is actually inserting his penis. Id. at 80I. Bigler suggests the woman who suffers from a fraud-in-the-inducement may actually feel doubly violated. Id.

"The doctor violated the patient's body and concealed it by manipulating the patient's mind." Id. 
clear that many men would be upset if they discovered that they had engaged in sexual relations with someone they thought was biologically female but was not. Questions as to how, if at all, the law should respond to these tensions and whether the law should be used to send a message that killing a transgender woman in such a situation is wrong, however, remain. We believe that the law should send such a message because of the particularly vulnerable status of transgender individuals in today's society. A legislative ban on trans panic arguments, however, would not necessarily eradicate the bias that underlies both the defendant's violence and the appeal of the trans panic defense. Therefore, we propose reforms aimed at eradicating the structures of masculinity that make trans panic arguments persuasive. The reforms we propose express the message that killing a transgender woman because of her gender identity is wrong, but do so more indirectly than a legislative ban. The reforms we propose also leave the decision as to whether to mitigate in the hands of the jury, whereas a legislative ban takes this decision away from the jury.

Most critics of the trans panic defense have advocated either a judicial or a legislative ban, much like the ban proposed by the ABA in August 2013 and the ban enacted by the California legislature a few months ago. A ban would send a strong message to would-be killers that it is morally reprehensible to kill a transgender woman because her biological sex does not match her gender identity.

One problem with a ban, however, is that it is unclear whether this message would reach the men most in need of hearing it. Much of the violence committed against gay and gender-nonconforming individuals is perpetrated by young males. ${ }^{235}$ These individuals may not read the newspaper or watch the news regularly enough to hear about the passage of a ban. But even if a ban on the trans panic defense would not deter the individuals most in need of deterrence, a ban would serve an important expressive function. It would send a loud and clear message that our society abhors this kind of violence. It would be an important statement, particularly in light of the fact that very few legal protections exist today for transgender individuals who face high rates of discrimination and violence.

A ban on the trans panic defense would also limit the effectiveness of the trans panic argument. Even if the defendant were to take the stand and testify that he was upset by the discovery that the person with whom he had been sexually intimate was biologically male rather than

235. Nat'l Coal. of Anti-Violence Programs, supra note 82, at 42, 44 (noting that $43.9 \%$ f those responsible for anti-LGBT violence are male and 32.7\% re between the ages of twenty-five to twentynine). See Gary David Comstock, Violence Against Lesbians and Gay Men 59 (Richard D. Mohr ed., I99I) ("[N]early one half of all perpetrators [of anti-gay/lesbian violence] are twenty-one years of age and younger, with the great majority less than twenty-eight years old."). 
biologically female, his argument would have no legal significance if the jury were not given a voluntary manslaughter/provocation instruction. In other words, even if the jury was sympathetic to the defendant's argument, they would not have a legal hook with which they could show their sympathy for the defendant. Of course, the jury could exercise its power to nullify and acquit the defendant despite overwhelming evidence of guilt, but this possibility exists in all criminal cases. ${ }^{236}$

While we recognize that the ABA's proposed legislative ban on gay and trans panic defense strategies would serve an important expressive function, we also feel that enacting such a ban would involve significant costs. First, if a legislature can categorically ban defendants from making trans panic arguments because it believes such arguments are morally reprehensible, it could categorically ban other defense arguments on moral grounds as well. Using the criminal law to dictate morality is deeply problematic given the constantly shifting and culturally contingent nature of morality. ${ }^{237}$ More importantly, a ban hearkens back to the early common law's rigid categorical approach to provocation, wherein only certain categories of provocative acts constituted legally adequate provocation. A ban on certain types of arguments is simply the converse of the early common law's categorical approach to provocation.

Second, a legislative ban, by its very nature, is bound to be overinclusive. The legislature cannot possibly foresee every possible scenario in which a defendant may assert a trans panic argument, yet a ban would preclude all defendants from raising any argument that references the victim's gender identity as the source of the defendant's loss of selfcontrol. We think it would be better to let judges and juries decide on a case-by-case basis whether to reject the provocation defense than for a legislature to categorically preclude all provocation arguments of a certain nature.

Third, a legislative ban on trans panic arguments would force the jury to make an all-or-nothing choice. In a jurisdiction where jurors are likely to sympathize with the defendant claiming gay or trans panic, a ban could result in more victories for defendants claiming trans panic, since jurors who believe murder is too harsh would not be permitted to find the defendant guilty of the lesser offense of manslaughter. In the

236. See generally Paul Butler, Let's Get Free: A Hip Hop Theory of Justice (2009) (urging jurors to nullify in cases involving defendants charged with nonviolent drug offenses); see also Jenny E. Carroll, Nullification as Law, I02 GEO. L.J. 579 (20I4) (arguing that jury nullification is consistent with notions of the rule of law).

237. In Lawrence v. Texas, the U.S. Supreme Court rejected morality-based criminalization. See Lawrence v. Texas, 539 U.S. 558, 577-78 (2003) ("[T]he fact that the governing majority in a State has traditionally viewed a particular practice as immoral is not a sufficient reason for upholding a law prohibiting the practice . . . .”); see also J. Kelly Strader, Lawrence 's Criminal Law, I6 BERKELEY J. CRIM. L. 4I (20II) (concluding that the Lawrence decision unquestionably rejects morals-based criminal laws). 
King case, for example, a majority of the jurors felt that King brought on his own demise by dressing like a girl and being flirtatious with the defendant, Brandon McInerney. ${ }^{238}$ The jury was split over whether the appropriate verdict was murder or manslaughter, with the majority in favor of manslaughter. If the jury had to choose between finding McInerney guilty of murder or not guilty of any homicide, some of the jurors who thought manslaughter was more appropriate than murder might have voted to acquit rather than find McInerney guilty of murder. An all-or-nothing choice may also result in more hung, juries since there is less room for compromise when the only choices are a murder conviction or a complete walk for the defendant.

Fourth, the defendant has a constitutional right to testify, so even if the legislature were to enact a ban on trans panic defense arguments, the defendant would still have a constitutional right to tell his side of the story, and his story could include mention that he got tremendously upset upon discovering that his intimate partner was biologically male. ${ }^{239}$ Jurors who are not already sensitive to the violence and discrimination leveled against the transgender community may be reluctant to condemn the defendant who claims he was provoked into a heat of passion by the discovery that the individual with whom he was intimate was biologically male.

Finally, a legislative ban is a big hammer when a gentle nudge might be a more effective way to get jurors to do the right thing. As Dan Kahan has shown through empirical studies, big changes in the law intended to punish individuals the legislature thinks are deserving of but escape punishment under the current legal regime are usually ineffective at changing juror attitudes and behavior and can even exacerbate the problem the law is attempting to address. ${ }^{240}$ Kahan explains, "[i]f the law condemns the conduct substantially more severely than does the typical decisionmaker, the decisionmaker's personal aversion to condemning too severely will dominate her inclination to enforce the law, and she will

238. See supra note I45. See also Letter from Juror Number I I to Dist. Att'y Gregory D. Totten, supra note 156 .

239. The defendant may also be permitted to call witnesses to testify on his behalf, even when the purpose of such testimony is to bolster the defendant's claim that a reasonable man would have been upset by the discovery that he had engaged in sexual relations with a transgender female. In the Shepard case, for example, even though the trial judge barred the defense from arguing gay panic provocation, he permitted the defense to call witnesses to the stand whose testimony supported the defense claim that it was reasonable for a heterosexual man to be very uncomfortable and upset by a gay man's sexual overtures. See Lee, supra note 3, at 527.

240. Dan M. Kahan, Gentle Nudges vs. Hard Shoves: Solving the Sticky Norms Problem, 67 U. CHI. L. REv. 607, 607-08 (2000) (illustrating that changing the law in a big way generally is ineffective at changing people's actual attitudes and behavior, whereas smaller, more incremental changes in the law are more likely to be effective at changing attitudes and behavior). 
balk." "24I On the other hand, if "the law condemns the behavior only slightly more than does the typical decisionmaker, her desire to discharge her civic duties will override her reluctance to condemn, and she will enforce the law." 242

What about anti-bias jury instructions? We agree with the ABA that a judge should be required to give an anti-bias instruction upon the request of either party. We would go further and permit judges to act sua sponte, giving an anti-bias instruction on their own motion whenever they feel it appropriate. We caution, however, that anti-bias jury instructions alone are not likely to be sufficient to temper the bias of a jury that is inclined to see the sexual activity of gay men and transgender women as sexually deviant. The King case illustrates this problem. The jury deciding whether to convict McInerney was given an anti-bias jury instruction based on the Araujo Act, ${ }^{243}$ yet seven of the twelve jurors more than half of the jury - felt a murder conviction was too harsh. ${ }^{244}$

Given the problems identified, we argue that it is critical to combat the underlying structures of masculinity that encourage violence against transgender females in the first place to both reduce the risk of such violence taking place and undermine the effectiveness of the trans panic defense strategy. Such reform must take place in the court of public opinion as well as in the specific courtroom where the trans panic argument is being asserted. Indeed, we feel that the place where such reform is likely to have the most impact is the court of public opinion. Therefore, television shows, movies, and plays may be more effective at getting this message across to the public than the criminal courtroom.

While perhaps not the most effective venue, the criminal courtroom remains one venue for potential reform. Prosecutors in cases involving transgender victims should first try to humanize the transgender victim. Jurors unfamiliar with gender identity issues may feel uncomfortable with the victim having had sexual relations with the defendant if she was not completely forthcoming about her biological sex. ${ }^{245}$ If jurors are not

24I. Id. at 608

242. Id. For the foregoing reasons, we do not offer a legislative ban on gay or trans panic arguments as one of our own proposals for reform. We would not, however, be opposed to such a ban if a legislature should choose to enact one.

243. See Conversation between Cynthia Lee and Maeve Fox, supra note I55.

244. See Mistrial Declared in Killing of Gay California Student, supra note I43.

245. In some cases, there is much reason to doubt the defendant's claim that he was provoked into a sudden heat of passion from the discovery that the victim was a transgender woman. For example, in one case out of Colorado, Allen Andrade argued he was provoked into a heat of passion after discovering Angie Zapata, a transgender woman with whom he had been sexually intimate, was biologically male, but evidence presented at his murder trial showed Andrade met Zapata through a website that catered to gay and transgender individuals. Nicholas Riccardi, Man Guilty of Hate Crime in Transgender Slaying, L.A. Times, Apr. 23, 2009, at Ai6. Prosecutors also presented evidence that Andrade accompanied Zapata to traffic court, where clerks called Zapata "Justin," as further proof 
educated about what it means to be a transgender individual, this discomfort may translate into sympathy for the defendant's violent acts.

The prosecutor should try to educate jurors about what it means to be a transgender woman and why disclosure may have been difficult for the victim. Sherry Colb offers a useful analogy that prosecutors could use in opening statements to help jurors better understand the transgender individual's predicament:

$[T]$ he transgender female's assigned or anatomical sex differs from her own sense of herself as female. We can appreciate this by imagining going to the doctor and learning that our own chromosomal sex is the opposite of our assigned sex. Imagine, if you are a woman, going to the doctor and finding out that you have an XY chromosome. If you are not a transgender person, then you would likely find this news quite distressing. This is at least in part because you have a gender identity, and that identity would remain in place even if you found out that you were mistaken about your chromosomal sex. You could not easily start thinking of yourself as a man simply because you found out that your chromosomes are XY. Like a transgender person, you have a gender identity whose existence is separable from your assigned sex at birth. ${ }^{246}$

Transgender men and women may be reluctant to disclose their biological sex to potential intimate partners out of fear that revealing this information will lead to violence. ${ }^{247}$ Janet Mock, a transgender woman and author, describes how a man who had been courting her for several weeks reacted when she disclosed her transgender identity:

As we pulled up in front of my apartment building, Adrian asked, "When can I see you again?"

I smiled, aware that this would be the last time he would look at me with the glow that comes from the newness of infatuation.

"That's sweet, but I'm not like other girls, you know?" I began.

"I like that about you," he said cheekily. I could tell by his playful expression that he had no idea about my past, about my present, about the girl he had been wooing for the past two weeks.

"I'm being serious. I'm not like other girls," I stammered. "I was born with the wrong parts and am waiting to have surgery to change that." I was vague on purpose; having to say that I'd been born a boy and was years and thousands of dollars away from having any kind of surgery was a reality I couldn't own up to yet.

He pulled away instantly. His face turned from the sweet, soft-eyed expression I had admired to one that was coarse, suited not for a girl but for men preparing for battle. I was afraid I had made a tragic mistake, telling him in his car with no one around.

that Andrade was aware of Zapata's biological sex well before he killed her. Id. Andrade's trans panic defense strategy was unsuccessful; he was convicted of first-degree murder and a hate crime. Id.

246. Sherry F. Colb, A Restroom of One's Own: The Maine Supreme Court Considers a

Transgender Student's Exclusion from the Girls' Bathroom, Verdict (June 26, 2013), http://verdict.justia.com/2013/o6/26/a-restroom-of-ones-own.

247. Моск, supra note 33 , at I6I. 
"I can't believe this," he said, not so much to me but to himself. "Why didn't you tell me earlier?"

Because you'd look at me the way you looking at me now, like some creature from a faraway land, void of human feeling, I wanted to say. I could hear his disgust in his tone, see it in his expression. I was no longer an attractive woman he was eager to see again; he perceived me as something artificial. To Adrian, I was this inauthentic woman trying to deceive him, possibly with the intention to get him into bed. In our patriarchal culture that values masculinity over femininity, my disclosure shook Adrian, challenging his heteronormative and cisnormative ideals.

"Sorry," I said, apologizing for who I was, ashamed of who I was, too young to know the right thing to have done. "I just didn't know how to tell you."

"I'm not like that. I'm not gay," he said, shaking his head. "This is just too much."

Heartbroken, I opened the car door, crying over how this would be the first of a long line of romantic rejections, how no man would ever love me because I was a different kind of girl, how unlucky I was. Now, over a decade later, I look at how lucky I was to walk out of Adrian's car, to cry in my bed, to wake up the next day. I now know that the world can be a brutal place for a girl with a penis. ${ }^{248}$

Second, because the provocation defense turns on whether the jury believes the defendant was reasonably provoked, what the jury thinks constitutes legally adequate provocation is key. Currently, reasonableness is equated with typicality. ${ }^{249}$ Under this conception of reasonableness, if the average or ordinary man would have been provoked into a heat of passion by the discovery that he had been sexually intimate with someone who was born with male genitalia, then the defendant was reasonably provoked. So long as reasonableness remains equated with typicality, a jury may be more likely to mitigate in the defendant's favor if they think most (heterosexual) men would be distraught and upset if they found out they had sex with a transgender female.

Reasonableness does not have to be equated with typicality. Reasonableness can and should be understood as a normative limitation on the provocation doctrine. ${ }^{250}$ The judge can explain to the jury that in order to find legally adequate provocation, the jury must make an assessment as to whether the defendant's loss of self-control was normatively appropriate given the circumstances. By making the normative function of the reasonableness requirement explicit, the law can gently nudge jurors to engage in more careful deliberation.

248. Id. at I59-61.

249. See Dressler, supra note 9 , at 73 I-32.

250. See LEE, supra note I02, at 226-59 (arguing that judges should supplement the current conception of reasonableness as that which is typical with a normative conception of reasonableness). 
How can the normative nature of the reasonableness requirement in provocation law be explained to jurors? Peter Westen suggests a jury instruction that captures the idea that the provocation defense should include a normative focus. Westen suggests that in deciding whether the defendant was reasonably provoked, the jury should be instructed as follows:

"Ladies and gentlemen of the jury":

. .

Existence of Anger. "First, you must decide whether the defendant was so angry when he killed his victim that it was much more difficult for him than if he were cool-headed to refrain from striking at his victim. If you find beyond a reasonable doubt that the defendant was not so upset, you shall return a [verdict] of murder. Otherwise, you must turn to the second step."

Reasonableness of Anger. "The second step concerns the nature of defendant's anger. You must decide whether it was reasonable for the defendant to be so upset."

The Defendant's Traits. "To do so, you shall start by taking the defendant as he is-with one important exception that I'll discuss in a moment. That he is, you shall consider everything you know about the defendant-including every physical characteristic, every experience, every personal relationship to others, and every emotional and temperamental disposition he may have."

The Defendant's Values. "Nevertheless, there is one thing about the defendant you shall not take into account. You shall not consider his own personal views, or the particular views of his ethnic community, about what it is right to be extremely angry about. Rather, you shall judge the reasonableness of his anger by how angry you, as representatives of the people of the state, conclude an individual who is otherwise like him is right to feel-or at least, not wrong to feel-in response to what actually upset him." 25 r

While we do not agree with Westen that the jury should necessarily take into account all of the defendant's characteristics and experiences in assessing the reasonableness of his claim of provocation, Westen's proposed jury instruction appropriately encourages the jury to consider societal views on whether the defendant had a right to feel upset. In other words, Westen's proposed jury instruction directs the jury, in judging the reasonableness of the defendant's loss of self-control, to consider the normative question of whether society thinks the defendant was right to be upset. Westen uses the example of a defendant claiming

\footnotetext{
25I. Westen, supra note I07, at I58. Since publication of his 2008 article, Westen has modified his views on which characteristics of the defendant may be considered by the jury. Westen now believes the jury should be allowed to take into account the defendant's idiosyncratic values and thanks law professor Jonathan Witmer-Rich for this change in thought. E-mail from Peter Westen, Frank G. Millard Professor of Law Emeritus, The University of Michigan Law School, to Cynthia Lee (Feb. 6, 20I4, I:44 PM) (on file with Cynthia Lee).
} 
gay panic to explain how his proposed jury instruction would work. If "the jury finds that the defendant's anger was the product of unacceptable homophobia that he could have learned to suppress, it would fault him for his anger and return a verdict of murder." ${ }^{252}$ A prosecutor in a trans panic case can similarly argue that, if the jury finds the defendant's anger was the product of unacceptable transphobia that the defendant should have controlled, they should fault him for his anger and return a verdict of murder.

Third, the prosecutor can seek to proffer expert witness testimony about the cultural structures of masculinity that may have contributed to the defendant's violent acts. Prosecutors must be careful to explain why fear of being seen as gay is not a legitimate reason to lose one's selfcontrol or this kind of testimony may make jurors even more sympathetic to the defendant. Jurors might conclude that the defendant was reasonably provoked because most men would have been equally upset. Here, it is critical that the prosecutor explain that the reasonableness requirement is a normative limitation on the provocation defense and that reasonableness should not simply be equated with typicality. If jurors are instructed to assess the reasonableness of the defendant's emotional upset from a normative perspective rather than simply equating reasonableness with typicality, they should conclude that it was not normatively appropriate for the defendant to take his anger, frustration, and fear of being seen as gay out on the victim.

The defense is likely to object to such expert testimony on the ground that it is not relevant. The prosecution can counter by arguing that social framework testimony is used in other contexts, albeit primarily to help defendants rather than the government. ${ }^{253}$ For example, courts today routinely permit defendants to put on expert witnesses to testify about problems involving eyewitness misidentification. ${ }^{254}$ Courts today also generally allow female defendants accused of murdering their abusers to put on expert witness testimony about battered women's syndrome to help the jury assess the reasonableness of the defendant's claim of self-defense. ${ }^{255}$ Educating jurors on ways that men prove their masculinity to themselves and others may help jurors understand why a man might have been motivated to kill a transgender woman upon discovering her biological sex.

252. Westen, supra note I07, at I59.

253. Neil J. Vidmar \& Regina A. Schuller, Juries and Expert Evidence: Social Framework Testimony, 52 L. \& Contemp. Probs. I33 (1989).

254. See generally D. Duff McKee, Challenge to Eyewitness Identification Through Expert Testimony, in 35 Am. Jur. 3d Proof of Facts i I-I8 (1996) (tracking historic exclusions and more inclusion of expert testimony on eyewitnesses).

255. See Martha R. Mahoney, Legal Images of Battered Women: Redefining the Issue of Separation, 90 Mich. L. Rev. I, 3 (I99I) (noting that many states allow expert testimony on battered women syndrome). 
Finally, prosecutors may be able to start changing public attitudes about the trans panic defense strategy by clever relabeling of the defense. Calling the defense strategy the "trans rage" defense rather than "trans panic" might evoke less sympathy for the defendant. ${ }^{256}$ Trans panic suggests a reason to be sympathetic to the defendant-he panicked and could not help himself. Trans rage, on the other hand, suggests a reason to condemn the defendant's actions: the defendant was overcome with an irrational and socially unacceptable rage, which led him to kill the victim.

One might object to our proposals for reform on the ground that a legislative ban ensures that no defendant who kills a transgender woman can "get away" with murder by asserting a claim of trans panic, whereas our proposals leave the decision in the hands of the jury, allowing the possibility that some defendants who assert a trans panic defense will succeed in getting the voluntary manslaughter mitigation. Indeed, mitigation is particularly likely to happen in jurisdictions where the community has negative views of gay and transgender people. We recognize this possibility, but feel it is best to let juries, which reflect community attitudes, decide these sorts of questions. Perhaps we are being foolishly optimistic, but we think that the jury will do the right thing if the prosecution educates the jury in the ways discussed above and if jurors are instructed to assess the reasonableness of the defendant's actions from a normative perspective. ${ }^{257}$

Even if a trans panic defendant "gets away" with murder, he will still have to serve time in prison for voluntary manslaughter because provocation is only a partial defense to murder. Moreover, the judge can sentence the defendant to the high end of sentences authorized for voluntary manslaughter, which may be close to the sentence he would have received if convicted of second-degree murder. ${ }^{258}$ The broad discretion of the sentencing judge can thus result in a flattening effect. ${ }^{259}$

The problem in many of these trans panic cases is that the prosecution thinks they cannot secure a murder conviction, so they allow

256. We thank Anupam Chander for this helpful suggestion.

257. In the Araujo case, jurors at their first trial agreed that Merel and Magidson were guilty of murder; they just could not agree on whether the defendants should be found guilty of first- or seconddegree murder. Wronge, supra note I65 (noting that in Merel's case, two jurors voted in favor of firstdegree murder while ten jurors voted against, and in Magidson's case, seven jurors voted in favor of first-degree murder while five voted against). On retrial, the jury found both defendants guilty of second-degree murder. People v. Merel, No. A I I3056, 2009 WL I3I4822, at *9 (Cal. Ct. App. May I2, 2009); Wronge, supra note I5I. In the Allen Andrade case, discussed supra note 245, the jury found the defendant guilty of first-degree murder. Riccardi, supra note 245 .

258. See, e.g., CAL. Penal Code $\$ \S$ igo(a), I93(a) (West 20I4) (assigning a high sentence of eleven years for voluntary manslaughter and a low sentence of fifteen years for second-degree murder); VA. CodE ANN. \$§ I8.2-32, I8.2-35 (West 20I4) (assigning a sentence of between one and ten years for voluntary manslaughter and a sentence of between five and forty years for second-degree murder).

259. We thank Joshua Dressler for this insight. 
the defendant to plead guilty to manslaughter. In these plea-negotiated cases, the jury never gets to consider and reject the defendant's claim of trans panic. Prosecutors plead out the vast majority of all cases, so this is not a problem unique to trans panic cases. ${ }^{260}$ Prosecutors usually plead out cases they think will be difficult to win. We think prosecutors can strengthen their chances of securing a murder conviction if they educate jurors in the ways we propose.

Why not simply abandon the reasonableness requirement in the law of provocation, replacing it with language that more clearly gets across the notion of normative appropriateness?26r We think legislatures are likely to be resistant to making wholesale changes to the doctrine of provocation. Eliminating the reasonableness requirement in provocation doctrine would likely be seen as a very radical change. It might be easier to convince a trial judge to instruct the jury to understand reasonableness as a normative limitation on the provocation defense than to get the judge to change the law of provocation by eliminating the reasonableness requirement. Trial judges, after all, are often worried about being reversed. All judges, however, are in the business of interpreting statutes. Interpreting the words "reasonable" and "reasonably" in the ways that we propose would be an easier change to implement. Even if the judge refuses to instruct the jury as we suggest, the prosecutor could argue to the jury that the reasonableness requirement imposes a normative limitation on the doctrine, and thus get jurors to think about whether the defendant's loss of self-control was normatively appropriate.

One might also object to our proposal by suggesting that a legislative ban is not so bad because the defendant can always argue trans panic at sentencing. ${ }^{262}$ Allowing the defendant who has been convicted of murder to argue for a lighter sentence is small consolation to the defendant who wishes to convince the fact finder that he should not be convicted of murder in the first place. While neither of us would find a trans panic argument persuasive, we are not convinced that our own view of what is normatively inappropriate behavior should be imposed on all jurors in all cases. Moreover, we do not believe legislatures should make it a habit to restrict the ability of criminal

260. Padilla v. Kentucky, 559 U.S. 356, 372 (2010) (noting that guilty pleas account for ninety-five percent of all criminal convictions); Stephanos Bibas, Plea Bargaining Outside the Shadow of Trial, I 77 Harv. L. Rev. 2464, 2497 (2004) (finding ninety-four to ninety-five percent of defendants plead guilty); Stephanos Bibas, Regulating the Plea-Bargaining Market: From Caveat Emptor to Consumer Protection, 99 Calif. L. Rev. III7, II38 (201 I) (stating that plea bargaining "is no longer a negligible exception to the norm of trials; it is the norm").

26I. We thank Kevin McGunigal for asking this question and giving us the opportunity to address it in this paper.

262. We thank Steve Morrison for this suggestion. 
defendants, especially those facing lengthy sentences, to assert a defense. ${ }^{263}$

Fortunately, there is reason to be hopeful that public attitudes are changing and becoming more accepting of transgender individuals and more sympathetic to their concerns. In the end, changing people's attitudes about transgender individuals is the best way to end the violence and discrimination that transgender people suffer and undercut the trans panic defense strategy. For an example of such a change, in 2012, the Miss Universe organization, owned by Donald Trump, initially disqualified Canadian Jenna Talackova from participating in the Miss Universe Canada beauty pageant because she was a transgender woman. ${ }^{264}$ Talackova, a twenty-three year old, six-foot one blonde Canadian, said that she knew she was a girl at age four, started hormone therapy at age fourteen and underwent sex reassignment surgery at the age of nineteen, four years prior to the competition. ${ }^{265}$ Talackova won a regional beauty competition, qualifying her for Canada's national title, but was told the Miss Universe Canada pageant was only open to naturally born females. ${ }^{266}$ Talackova's attorney, Gloria Allred, blasted Trump for Miss Universe Canada's initial position, saying Talackova "did not ask Mr. Trump to prove that he is a naturally born man or to see photos of ... his anatomy to prove that he was male."267

On April I2, 20I2, Trump shifted the pageant's position, stating that Talackova could compete in the Miss Universe beauty pageant as long as she met Canada's legal requirements for gender identity recognition. ${ }^{268}$ Later in 20I2, Olivia Culpo, the winner of the Miss USA competition, was asked during the interview portion of the competition whether she felt it would be fair if a transgender woman won the Miss USA title over a natural-born woman. ${ }^{269}$ Culpo responded:

"I do think that that would be fair, but I can understand that people would be a little apprehensive to take that road because there is a tradition of natural-born women," ... . "But today where there are so

263. We realize that the Supreme Court has held it is constitutionally permissible for a legislature to prohibit the defendant from putting forth evidence of voluntary intoxication or mental illness to negate the mens rea required for commission of the offense and disagree with those cases. See Montana v. Egelhoff, 5 I8 U.S. 37 (1996); Clark v. Arizona, 548 U.S. 735 (2006).

264. Suzi Parker, Forget Miss Universe, Stand Up for Women, Wash. Post Blog (Apr. I2, 2012, 4:Io PM), http://www.washingtonpost.com/blogs/she-the-people/post/jenna-talackova-forget-missuniverse-stand-up-for-women/20I2/o4/I2/gIQAwm INDT_blog.html.

265. Alan Duke, Donald Trump vs. Gloria Allred: Transgender Beauty Battle, CNN (Apr. 4, 20I2, 6:06 AM), http://www.cnn.com/20I2/04/04/showbiz/transgender-beauty-battle.

266. Id.

267. Id.

268. Id.

269. Miss USA Olivia Culpo Supports Transgender Pageant Contestants; Donald Trump Likes Her Answer, Fox News (June 4, 20I2), http://www.foxnews.com/entertainment/2012/06/04/miss-rhodeisland-olivia-culpo-crowns-miss-usa-supports-transgendered-pageant. 
many surgeries and so many people out there who have a need to change for a happier life, I do accept that because I believe it's a free country." 270

Donald Trump told reporters that he thought the question was a tough one and that Culp "gave a great answer" to the question. ${ }^{271}$

In November 2013, a sixteen-year-old male set fire to a gender nonconforming teenager named Sasha while Sasha was dozing on a bus, causing severe burns to Sasha's legs and body. ${ }^{272}$ There was an immediate outpouring of public support for Sasha and condemnation of the teen who set Sasha on fire. ${ }^{273}$ The teen was charged as an adult with a hate crime, aggravated mayhem, and felony assault. ${ }^{274}$ The local media featured Sasha's story for weeks, from the day Sasha was burned until Sasha returned home from the hospital. Sasha's cousin set up a webpage to help Sasha with a speedy recovery and raised more than \$21,000 in one day to help pay for Sasha's surgery. ${ }^{275}$

On June 9, 20I4, Time Magazine ran a cover story entitled, The Transgender Tipping Point: America's Next Civil Rights Frontier. The article presented a very positive portrayal of transgender people. ${ }^{276}$ It noted that in the fall of 20I3, students in Huntington Beach, California elected a transgender woman as their homecoming queen. ${ }^{277}$ This was particularly striking given that Huntington Beach is in Orange County, a fairly conservative region of Southern California. ${ }^{278}$

These are just a few examples of changing public attitudes about transgender people. As further evidence of increasing public attention to issues concerning transgender individuals, on January 6, 20I4, Katie Couric interviewed two transgender women, Orange is the New Black actress Laverne Cox and model Carmen Carrera, on her show, Katie. ${ }^{279}$ 
Additionally, on February 4, 20I4, Piers Morgan of Piers Morgan Live interviewed Janet Mock, a transgender woman who recently published a book, entitled Redefining Realness. ${ }^{280}$ Janet Mock's book quickly made the number nineteen slot on the New York Times bestseller list for hardcover nonfiction. ${ }^{281}$ While Couric was critiqued for asking questions about her guest's genitalia ${ }^{282}$ and Morgan was similarly critiqued, ${ }^{283}$ the fact that both of these prominent news figures thought it important to have transgender women featured on their shows reflects a big step towards raising awareness about trans issues. Such steps are critical to reducing bias against transgender persons.

\section{CONCLUSION}

Americans are just starting to become engaged in dialogue with members of the trans community and with each other about issues affecting transgender individuals. The ABA resolution reflects such dialogue and augers well for the evolution of social justice and society as a whole. While a legislative ban on the trans panic defense is one way to express moral condemnation of men who kill transgender women upon discovering their biological sex, a legislative ban will not end anti-trans bias in the criminal justice system. To combat the trans panic defense, decisionmakers concerned about bias against transgender individuals must adopt measures that educate the jury and the public about what it means to be a transgender individual, why a transgender woman might not disclose her transgender status, and the structures of masculinity that make reliance on trans panic persuasive. Reasonableness in provocation law must also be reconceptualized such that reasonableness is no longer equated with typicality and is, instead, understood as a normative limitation on the provocation defense. This Article is an attempt to advance the eradication of these structures of masculinity through education, awareness, and dialogue.

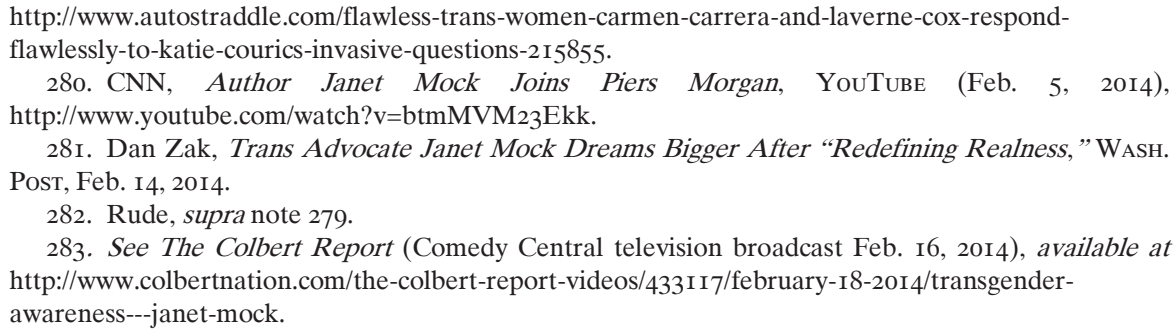

